\title{
Heterogeneity in the debt-growth nexus: Evidence from EMU countries
}

\author{
Marta Gómez-Puig ${ }^{\mathrm{a}^{*}}$, Simón Sosvilla-Rivero ${ }^{\mathrm{b}}$ \\ ${ }^{a}$ Department of Economics and Riskcenter, Universitat de Barcelona. \\ 08034 Barcelona, Spain \\ ${ }^{\mathrm{b}}$ Complutense Institute for International Studies, Universidad Complutense de Madrid. \\ 28223 Madrid, Spain \\ Revised version \\ July 2017
}

\begin{abstract}
The objective of this paper is to examine whether the threshold beyond which a public debt change may have a detrimental effect on economic growth changes across euro area countries during the 1961-2015 period. In contrast with previous studies, we do not use panel estimation techniques, but implement a time-series analysis for each country based on the growth literature. The results suggest that in all the countries but Belgium a debt increase begins to have detrimental effects on growth well before the SGP debt ceiling (a debt ratio of around $40 \%$ and $50 \%$ in central and peripheral countries, respectively) is reached. So, although austerity policies should be applied in EMU countries - since according to our results debt reduction barely exerts any significant beneficial impact on EMU countries' growth - they should be accompanied by structural reforms that can increase their potential GDP. Moreover, as our results suggest that the harmful impact of a debt change on growth does not occur beyond the same threshold and with the same intensity in all EMU countries, a focus on average ratios and impacts may be unsuitable for defining policies. Specifically, our findings suggest that the pace of fiscal adjustment should be lower in Greece and Spain than in the other countries.
\end{abstract}

Keywords: Public debt, economic growth, heterogeneity, multiple structural breaks, euro area, peripheral EMU countries, central EMU countries.

JEL Classification Codes: C22, F33, H63, O40, O52

\footnotetext{
* Corresponding author. Tel.: +34 934020113; fax: +34 934039082.

E-mail addresses: marta.gomezpuig@ub.edu (M. Gómez-Puig), sosvilla@ccee.ucm.es (S. Sosvilla-Rivero)
} 
"At the present stage of development in Economics it is probably an advantage to have

different groups looking at the same problem from different viewpoints, so that their conclusions can be compared and possibly then form the basis for a new compressive model"

Granger (1990, 1)

\section{Introduction}

Nine years after the onset of the Great Recession, recovery remains tepid and bumpy in the European Economic and Monetary Union (EMU), and the prospects remain uncertain. The recent economic crisis led to an unprecedented increase in public debt across euro area countries $^{1}$, raising serious concerns about its impact after a debt crisis that even called into question the stability of the euro. Troubled sovereign borrowers received financial rescue packages which were conditional on fiscal austerity and on the implementation of structural reforms to improve competitiveness.

In the light of the events of the last few years, there is widespread agreement about the potentially adverse consequences for the economies of EMU countries of their unparalleled levels of public debt. However, few macroeconomic policy debates have generated as much controversy as the current austerity argument [see Alesina and Ardagna (2010), Alesina et al. (2015), Guajardo et al. (2011) or Jordà and Taylor (2016)] and, as Europe stagnates, the disagreement appears to be far from over. The core of the debate revolves around identifying the right stabilization policies to implement or, in a context of low economic growth, establishing the right pace of adjustment: austerity measures may prove positive in the long run, but they are likely to have negative effects on demand and production during the adjustment period [see Cottarelli and Jaramillo (2013), Delong and Summers (2012), or Perotti (2012)].

Overall, the theoretical literature finds that there is cause to take into account the effects of very high debt on capital stock and growth, since it tends to point to a negative link between the public debt-to-Gross Domestic Product (GDP) ratio and the steady-state growth rate of GDP (see, for instance, Aizenman et al., 2007). The conventional view is that while debt can stimulate aggregate demand and output in the short run [see Barro (1990) or Elmendorf and Mankiw (1999)], in the long run it may crowd out capital and

\footnotetext{
${ }^{1}$ On average, public debt reached levels about $100 \%$ of Gross Domestic Product (GDP) - its highest level in 50 years by the end of 2013 .
} 
reduce output (Salotti and Trecroci, 2016). Moreover, the literature provides a variety of reasons to explain why the higher the level of public debt, the more negative its effects. Greiner (2014) points out that growth-impeding long-run effects are caused by changes in market participants' expectations at high levels of public debt, leading to an increase in interest rates and a decrease in investment; Teles and Mussolini (2014) stress that, as uncertainty rises, additional fiscal flexibility for productive government spending is reduced, with a negative effect on growth; whilst Cochrane (2011) emphasizes that the higher the levels of public debt, the greater their negative effects due to a climate of uncertainty in which economic actors expect future confiscation, in the form of either increasing inflation or distortionary taxation.

Against this background, the analysis in this paper will focus on the short-run effects of debt changes on economic growth in EMU countries with the objective to bring some light to the current austerity debate in a context of unprecedented debt levels. Therefore, we pose the following research questions: Does the effect of changes in the debt-to-GDP ratio on the short-run growth rate depend on the level of debt and the sign of the debt change? What is the debt-to-GDP threshold beyond which expansionary fiscal policies (a debt increase) have a negative impact on euro area economies' rates of growth? Does the shortterm effect of a debt variation on economic performance differ across euro area countries? If a heterogeneous nexus between debt and growth is found, should stabilization policies to consolidate public finances or the pace of adjustment within euro area countries differ?

These are important policy questions that need to be answered, but the results from the empirical literature in the EMU context do not provide a conclusive response since, despite the severe sovereign debt crisis, few papers have examined the relationship between debt and growth for euro area countries and the scant literature so far has mostly disregarded country heterogeneity in this relationship. Checherita-Westphal and Rother (2012) analyse the empirics of the debt-growth nexus using a standard growth model and panel data techniques and find that, during the 1970-2008 period, the turning point beyond which government debt negatively affects growth is $90-100 \%$ of GDP. Baum et al. (2013), who focused on the 1990-2010 period, detected a similar threshold by employing a dynamic approach (while the short-run impact of debt on per capita GDP growth is positive and significant, it decreases to zero beyond debt-to-GDP ratios of $67 \%$, and at ratios above 95\% additional debt has a negative impact on output growth). In contrast, Dreger and Reimers (2013)'s analysis is based on the distinction between sustainable and nonsustainable debt periods. Their results show that the negative impact of the debt-to-GDP 
ratio on growth in the euro area is limited to periods of non-sustainable public debt; instead, debt will exert a positive impact on growth given that it is sustainable. The three former studies are synthesized and extended by Antonakakis (2014). Like them he uses a panel approach, but in addition to debt non-linearities he also examines the role of debt sustainability in economic growth in the euro area.

Overall, the empirical literature mentioned above supports the presence of a common debt threshold across (similar) countries like those in the euro area favouring that so far the policy debate mostly ignored country heterogeneity in fiscal rules implementation. However, on the one hand, some recent literature has stressed that the effects of fiscal consolidation on economic activity, not only differ between core and peripheral countries (Anderson et al., 2014), but also across peripheral economies (Aldici et al., 2016). On the other hand, the latest literature on the debt-growth relationship suggests that the presence of a tipping point does not mean that it has to be common across countries.

Indeed, the review paper by Panizza and Presbitero (2013) triggered a new wave of studies analysing the heterogeneous growth effects of public debt ${ }^{2}$. According to Mitze and Matz (2015), whilst a "first generation" of empirical cross-country studies predominantly predicted an inverted U-shape relationship between public debt and economic growth, with a negative impact on growth particularly in highly indebted countries, more recently a "second generation" of empirical contributions has challenged those findings on various grounds, including uncontrolled sample heterogeneity. The "first generation" of papers include the works by Reinhart and Rogoff (2010), Pattillo et al. (2011), Lof and Malinen (2014) and Woo and Kumar (2015); whilst the "second generation" include Ghosh et al. (2013), Markus and Rainer (2016), Chudik et al. (2017), Pescatori et al. (2014) or Edberhardt and Presbitero (2015).

The latter authors propose a variety of reasons for the heterogeneity across countries in the debt-growth nexus. Ghosh et al. (2013) show that the turning point may be a function of countries' structural characteristics and GDP growth. Markus and Rainer (2016) point out that, due to specific institutional characteristics concerning fiscal flexibility, fiscal

\footnotetext{
2 See, e.g., Eberhardt and Presbitero (2015), who investigate the debt-growth relationship in 118 developing, emerging and advanced economies and find some evidence for nonlinearity, but state that there is no evidence at all for a common threshold level in all countries over time; Égert (2015), who presents empirical evidence suggesting that $90 \%$ (the threshold suggested in the seminal paper by Reinhart and Rogoff, 2010) is not a magic number since it may be lower and nonlinearity may change across different samples and specifications, or Gómez-Puig and Sosvilla-Rivero (2015), who examine the bi-directional causality between debt and growth in a sample of eleven EMU countries and find that public debt has a negative effect over growth from an endogenously determined breakpoint and above a debt threshold that differs depending on the country.
} 
effectiveness and fiscal consistency, different economic systems entail different degrees of fiscal uncertainty, which to a large extent shape the investment climate at comparable levels of public debt and thus constitute a source of heterogeneity in the relationship between high public debt levels and long-run economic growth. Chudik et al. (2017) and Pescatori et al. (2014) identify the debt trajectory as a source of heterogeneity in the debt-growth relationship, suggesting that high but falling public debt levels are growth-neutral while high and rising debt levels are detrimental for economic activity. Finally, according to Eberhardt and Presbitero (2015), there are many possible reasons for the differences in the relationships between public debt and growth across countries. First, production technology may differ across countries, and thus also the relationship between debt and growth. Second, the capacity to tolerate high levels of debt may depend on a number of country-specific characteristics, related to past crises and the macro and institutional framework. Third, vulnerability to public debt may depend not only on levels of debt, but also on its composition (domestic versus external, foreign or domestic currencydenominated, long-term versus short-term public debt), which may also differ significantly across countries.

Nevertheless, our study of the empirical evidence revealed hardly any analyses of the potential heterogeneity in the debt-growth nexus across euro area countries since the scarce literature on this topic belongs to the "first generation" of papers. Thus, to the best of our knowledge, this is the first paper to examine explicitly whether the debt-growth relationship may differ across EMU countries depending on their particular idiosyncrasies. The study of whether the relationship between public debt and economic growth may vary across countries has a significant bearing in the euro area context because, if the impact of debt on growth differs according to country, a focus on the average relation may be misleading for the definition of policy in individual countries - especially in an environment in which some EMU countries are already obliged to apply adjustment plans that reestablish competitiveness and fiscal balance.

Hence, this paper aims to fill the existing gap in the literature by explicitly taking into account the possible heterogeneity in the relationship between debt and growth across euro area countries. Our paper, then, is closely related to the work by Eberhardt and Presbitero (2015) and covers a very similar period but, in contrast with their analysis, it centres on the short-run effects of debt on economic growth, focuses on a different sample of countries and applies a different methodology. Whereas those authors used total public debt data from 118 developing, emerging and advanced economies, we centre on 11 euro area 
countries. And with regard to the econometric methodology, instead of using panel estimation techniques that allow for heterogeneous limits across countries, we explore the time series dimension of the issue to obtain further evidence based on the historical experience of each country in the sample in order to detect potential heterogeneities in the relationship across euro area countries. In so doing, by taking into consideration the stationary or non-stationary nature of the variables under study, we can properly use hypothesis tests to examine the statistical significance of the estimated coefficients.

The rest of the paper is organized as follows. Section 2 presents the rationale for our empirical approach on the basis of the results of some preliminary descriptive analyses. Section 3 introduces the analytical framework. Section 4 describes the data used in the analysis. Empirical results are presented in Section 5 and some extensions are incorporated in order to explore the possibility of asymmetric effects and to identify threshold effects. Finally, some concluding remarks and policy implications are provided in Section 6.

\section{Preliminary descriptive analysis}

In the following, we provide some descriptive analyses highlighting the cross-country heterogeneity in the relationship between debt and growth in euro area countries. Figure 1 shows the evolution of net sovereign debt-to-GDP and real GDP per capita growth in the 11 countries in our sample (Austria, Belgium, Finland, France, Germany, Greece, Ireland, Italy, the Netherlands, Portugal and Spain) over the sample period 1961-2015.

[Insert Figure 1 around here]

Some interesting insights can be drawn from Figure 1, which shows that the debt-to-GDP ratio reached its peak at the end of the sample period in all the countries in our sample, with the exceptions of Belgium, Finland, and the Netherlands where the highest ratio coincided with the economic crisis of the early 1990s. So, leaving these three countries aside, the recent economic and financial crisis led to an unprecedented increase in public debt-to-GDP ratios in the majority of EMU countries, even though their evolution over the 1961-2015 period exhibits different patterns. While in Ireland, Italy and Spain the notable rise in debt accumulation in 2007-2008 was preceded by a deleverage period; in Austria, France, Germany, Greece and Portugal debt presented an upward trend throughout the period, albeit at different speeds. With respect to GDP growth, although the evolution of the business cycle is quite similar in all EMU countries, the impact of the 
recessions (five according to the CEPR Euro Area Business Cycle Dating Committee ${ }^{3}$ : 1974:Q4-1975:Q1; 1980:Q2-1983:Q3; 1992:Q2-1993:Q3; 2008:Q2-2009:Q2; and 2011:Q42013:Q3) clearly diverges across countries.

All in all, Figure 1 indicates that the evolution of the two variables studied (net public debtto-GDP and GDP per capita growth) presents very different patterns across euro area countries. This suggests that an individual analysis of their relationship over time may capture the potential heterogeneity across countries and provide more useful information than a country-group analysis applying panel techniques.

Obviously, the above results are by no means conclusive, but they may challenge some of the implicit assumptions adopted in most of the previous literature regarding the relationship between debt and growth in similar countries, like those in the euro area. They thus provide a good reason to examine whether there may be some differences in this relationship across EMU countries depending on their level of economic development, their industrial structure, or the institutional environment.

\section{Analytical framework}

Economic models are inevitably incomplete characterizations of the complicated reality of economic life: "like rays of light they illuminate a part of a whole and leave the rest in dark" Hicks (1981, p.232). Therefore, formulating a sufficiently general initial model to capture all the substantively relevant influences is a fundamental problem facing all empirical modelling exercises (Doornik and Hendry, 2015).

The crucial decision in all empirical studies concerns the set of variables for which observations should be collected and then analysed, which will be a small subset of all the variables in the economy. Following both the relevant economic theory and the previous empirical results, our strategy incorporates the specification and estimation of a growth equation based on the growth literature (e.g., Barro and Sala-i-Martin, 2004) augmented by public debt to assess whether the latter has an impact on growth over and above other determinants.

The initial empirical specification is derived from the neoclassical growth model of Solow, where the growth rate of real per capita GDP $\left(g_{t}\right)$ for a given country is:

\footnotetext{
3 The CEPR Euro Area Business Cycle Dating Committee establishes the chronology of recessions and expansions of the eleven original euro area member countries plus Greece for 1970-1998, and of the euro area as a whole from 1999 onwards (see Centre for Economic Policy Research, 2014).
} 


$$
g_{t}=\alpha+\gamma y_{t-1}+\sum_{i=1}^{n} \delta_{i} X_{i t}+\beta d_{t}+\varepsilon_{t}
$$

where $y_{t-1}$ is the logarithm of initial real per capita GDP (to capture the "catch-up effect" or conditional convergence of the economy to its steady state), $X_{i t}(i=1, \ldots, \mathrm{n})$ is a set of explanatory regressors and $d_{t}$ is the net public debt-to-GDP ratio.

Regarding $X_{t}$, we consider a set of explanatory variables that have been shown to be consistently associated with growth in the literature: population growth rate as a percentage $\left(P O P G R_{t}\right)$; the ratio of gross capital formation to GDP $\left(G C F_{t}\right)$; life expectancy at birth, a proxy for the level of human capital $\left(H K_{t}\right)^{4}$; openness to trade, measured by the absolute sum of exports and imports over GDP $\left(O P E N_{t}\right)$; and the GDP deflator inflation rate, a measure of macroeconomic instability and uncertainty $\left(I N F_{t}\right)$.

In the economic growth literature, the rate of growth of labour used in the production process and the accumulation of physical capital (investment) are the key determinants of growth (Solow, 1956 or Frankel, 1962). So, population growth $\left(P O P G R_{t}\right)$ and the ratio of gross fixed capital formation to real GDP $\left(G C F_{t}\right)$ are used to proxy country size and the rate of labour growth and the accumulation of the physical capital stock respectively. The empirical evidence suggests that the relationship between population and economic growth is mixed and varies between countries. Some empirical studies suggest that the relationship is negative and insignificant (Levine and Renelt, 1992); others find a negative and significant association (Mankiw et al., 1992); whilst still others present evidence of a positive relationship (Sachs and Warner, 1997). The population growth rate, then, has been found to exhibit either a positive or a negative relationship with economic growth. However, according to many literature reports, a positive and statistically significant impact of physical capital stock (investment) on economic growth is expected ${ }^{5}$.

A proxy of human capital $\left(H K_{t}\right)$ is included to reflect the notion that countries with an abundance of human capital are more likely to be able to attract investors, absorb ideas from the rest of the world, and engage in innovation activities (Grossman and Helpman,

\footnotetext{
4 This proxy is also used by Sachs and Warner (1997). Other proxies commonly used for human capital such as years of secondary education and school enrollment in secondary were only available from 1980. Additionally, the proxy years of secondary education did not change during the sample period. As shown in Jayachandran and Lleras-Muney (2009), longer life expectancy encourages human capital accumulation, since a longer time horizon increases the value of investments that pay out over time. Moreover, better health and greater education are complementary with longer life expectancy (Becker, 2007). Indeed, life expectancy at birth correlates strongly with the index of human capital per person provided by the Penn World Table (version 8.0, Feenstra et al., 2013), based on years of schooling (Barro and Lee, 2013) and returns to education (Psacharopoulos, 1994).

${ }^{5}$ Investment and growth may also be associated through the savings ratio (Keynes, 1936).
} 
1991). Whilst some studies have found a positive relationship between human capital and economic growth (Radelet et al., 2001), others have found a negative relationship (Barro, 2003). Consequently, the effect of human capital on economic growth is expected to be either positive or negative. Trade openness $\left(O P E N_{t}\right)$ is posited to boost productivity through transfers of knowledge and efficiency gains (Seghezza and Baldwin, 2008). Since most of the empirical literature [Romer (1992), Barro and Sala-i-Martin (1995), or Edwards (1998), among others] provides evidence of the positive impact of openness on growth, a positive sign is expected for this variable. Finally, with regard to the inflation rate $\left(I N F_{t}\right)$, it has been argued that inflation is a good macroeconomic indicator of how the government manages the economy [see Fischer (1993) or Barro (2003), among other authors] and that low inflation brings about economic efficiency because, through the price mechanism, economies are able to allocate scarce resources to their best economic use (World Bank, 1990). Nonetheless, the a priori expectation may be either a positive or negative association between inflation and economic growth. This uncertain a priori effect is supported by the different arguments presented in the literature regarding the relationship between these two variables. Whilst some authors defend a negative relationship, others support a positive one. So, on the one hand, the former group includes De Gregorio (1993), who suggests that inflation can increase the cost of capital, reducing capital accumulation and lowering its productivity and thus inhibiting long-run growth; Friedman (1977), who conjectures that inflation uncertainty would reduce the effectiveness of the price mechanism to coordinate economic activities, decreasing the output growth rate; and Fischer (1993) or Bruno and Easterly (1998), who stress the negative relationship between inflation and growth especially via its impact on the efficiency of physical capital. On the other hand, the latter group includes Tobin (1965), who argues that higher anticipated inflation can increase capital per head as households shift their (portfolio) assets away from real money balances (non-interest-bearing money) toward real capital (more productive forms) and Dotsey and Sarte (2000), who contend that inflation makes the return to money balances uncertain and reduces the demand for real money balances and consumption; this increases precautionary savings and, in response to higher anticipated inflation, the investment pool enhances economic growth.

\section{Data}

We use annual data for eleven EMU countries: both central (Austria, Belgium, Finland, France, Germany and the Netherlands) and peripheral (Greece, Ireland, Italy, Portugal and 
Spain) ${ }^{6}$. We use long spans of data covering the 1961-2015 period (i.e., a total of 54 annual observations) to explore the dimension of historical specificity and to capture the underlying relationship between the variables under study.

To maintain as much homogeneity as possible for a sample of 11 countries over the course of five decades, we use the World Bank's World Development Indicators ${ }^{7}$ as our primary source. We then strengthen our data with the use of supplementary information from the International Monetary Fund (International Financial Statistics and World Economic Outlook, October 2016) and the European Commission's AMECO database. As mentioned above, we use per capita GDP at 2010 market prices, population growth rate, the ratio of gross capital formation to GDP, an index of human capital, openness to trade and GDP deflator inflation. The precise definitions and sources of the variables are presented in Appendix 1.

\section{Empirical Results ${ }^{8}$}

\subsection{Time series properties}

Our approach focuses on time series analyses of yearly data for individual countries which can help us to document the possible differences in their experiences. This approach is likely to provide an accurate idea of what underlies the debt-growth nexus in EMU countries.

Since the appropriate econometric treatment of a model depends crucially on the pattern of stationarity and non-stationarity of the variables under study, before carrying out the estimation we test for the order of integration of the variables by means of the Augmented Dickey-Fuller (ADF) tests. This step is necessary to ensure that all our variables in the regression equation have the same order of integration, given the non-stationarity that most macroeconomic data exhibit. The results decisively reject the null hypothesis of unit root at conventional significance levels for $g_{t}, I N F_{t}, P O P G R_{t}$ and $G C F_{t}$ (indicating that they are

\footnotetext{
${ }^{6}$ This distinction between European central and peripheral countries has been used extensively in the empirical literature. The two groups we consider roughly correspond to the distinction made by the European Commission (1995) between countries whose currencies continuously participated in the European Exchange Rate Mechanism (ERM) from its inception and which maintained broadly stable bilateral exchange rates with each other over the sample period, and those countries whose currencies either entered the ERM later or suspended their participation in the ERM, as well as fluctuating widely in value relative to the Deutschmark. These two groups are also roughly the ones found in Jacquemin and Sapir (1996), who applied multivariate analysis techniques to a wide set of structural and macroeconomic indicators, to form a homogeneous group of countries. Moreover, these two groups are basically the same as the ones found in Ledesma-Rodríguez et al. (2005) according to economic agents' perceptions of the commitment to maintain the exchange rate around a central parity in the ERM, and those identified by Sosvilla-Rivero and Morales-Zumaquero (2012) using cluster analysis when analyzing the permanent and transitory volatilities of EMU sovereign yields.

$7 \mathrm{http}: / /$ data.worldbank.org/data-catalog/world-development-indicators

${ }^{8}$ We summarize the results by pointing out the main regularities. The reader is asked to browse through Tables 1 to 6 to find evidence for particular country of her/his special interest.
} 
stationary in levels, i. e., I(0)), while we do not reject the null for $y_{t}, d_{t}, O P E N_{t}$ and $H K_{t}$ (suggesting that these variables can be treated as first-difference stationary, i. e., I(1)) . Then, following Cheung and Chinn's (1997) suggestion, we confirm these results using the Kwiatkowski et al. (1992) (KPSS) tests, where the null is a stationary process against the alternative of a unit $\operatorname{root}^{10}$. As can be seen in Figure 1 the growth rates are clearly stationary $\mathrm{I}(0)$, whereas $d_{t}$ appears to be I(1), highlighting the point made above.

\subsection{A basic empirical model}

Given that our dependent variable is stationary (i. e., its statistical properties such as mean, variance, autocorrelation, etc. remain constant over time), we cannot explain it with nonstationary variables (whose statistical properties change over time). Additionally, if the variables in the regression model are not stationary, then the standard assumptions for asymptotic analysis will not be valid and we cannot undertake hypothesis tests about the regression parameters. Therefore, by differencing the non-stationary variables we transform them into stationary variables. ${ }^{11}$.

As a result of the time series properties of our data, the baseline empirical model is as follows:

$$
g_{t}=\phi g_{t-1}+\delta_{1} I N F_{t}+\delta_{2} \Delta H K_{t}+\delta_{3} \Delta O P E N_{t}+\delta_{4} P O P G R_{t}+\delta_{5} G C F_{t}+\beta \Delta d_{t}+\varepsilon_{t}
$$

where $\Delta$ denotes the first difference operator.

Note that model (2) is quite different from model (1), which is commonly used in the literature, especially regarding the variables $y_{t-1}, H K, O P E N$ and $d$, since we find that they are non-stationary and therefore enter our model in first differences. As argued in Asimakopoulos and Karavias (2016), by rewriting equation (1) as (3)

$$
g_{t}=\alpha+\gamma y_{t-1}+\sum_{i=1}^{l} \delta_{i}^{s} X_{i t}^{s}+\sum_{i=1}^{l} \delta_{i}^{n s} X_{i t}^{n s}+\beta d_{t}+\varepsilon_{t}
$$

(where $X_{i t}^{s}$ and $X_{i t}^{n s}$ denote the stationary and non-stationary explanatory variables respectively), we can compare (3) with our equation (2), which has $g_{t-1}=\Delta y_{t-1}$ instead of $y_{t-1}, \Delta d_{t}$ instead of $d_{t}$ and $\Delta X_{i t}^{n s}$ instead of $X_{i t}^{n s}$ as explanatory variables due to non-

\footnotetext{
${ }^{9}$ These results (which are not shown here in order to save space, but are available from the authors upon request) were confirmed using Phillips-Perron (1998) unit root tests controlling for serial correlation and the Elliott, Rothenberg, and Stock (1996) Point Optimal and $\mathrm{Ng}$ and Perron (2001) unit root tests for testing non-stationarity against the alternative of high persistence. These additional results are also available from the authors.

10 The results are not shown here due to space restrictions but are available from the authors upon request.

${ }^{11}$ Note that if the public debt-to-GDP ratio series contains a unit root, that would imply that the results of many previous studies (some of which had been used as a basis for policy recommendations) are spurious.
} 
stationarity. The interpretation of the estimated parameters is the same in both models, but that of $\phi, \delta_{2}, \delta_{3}$ and $\beta$ changes $^{12}$.

\subsection{Exploring the possibility of asymmetric effects}

To explore the possibility of an asymmetric effect on positive and negative debt variations on economic growth for each country, we use the following alternative empirical specification to capture this possibility:

$$
\begin{aligned}
& g_{t}=\phi g_{t-1}+\delta_{1} I N F_{t}+\delta_{2} \Delta H K_{t}+\delta_{3} \Delta O P E N_{t}+\delta_{4} P O P G R_{t}+\delta_{5} G C F_{t} \\
& +\beta_{1} \Delta d_{t} I\left(\Delta d_{t}>0\right)+\beta_{2} \Delta d_{t} I\left(\Delta d_{t}<0\right)+\varepsilon_{t}
\end{aligned}
$$

where $I$ is an indicator function that takes the value 1 if the condition is fulfilled (i. e., if $\Delta d_{t}$ is positive or negative) and zero otherwise. The indicator function has the effect of splitting the debt change variable into two, allowing for its impact to differ depending on the sign of the change (i. e., debt accumulation and debt relief).

We employ a data-based method for obtaining a parsimony representation of the data generating process (DGP): the general-to-specific approach (Hendry, 1995). General-tospecific modelling seeks to mimic reduction by commencing from a general congruent specification which is simplified to a minimal representation consistent with the desired criteria and the data evidence. Starting from a general unrestricted model that contains all the variables likely to be relevant (based on the specification presented in equation 2) and lags long enough to be able to capture a constant parameter representation, standard testing procedures eliminate statistically-insignificant variables. Diagnostic tests check the validity of the reductions, ensuring a consistent final selection which produces a parsimonious and interpretable econometric model that is data admissible, presents wellbehaved residuals and uses conditioning variables that are weakly exogenous (see Faust and Whiteman, 1997) ${ }^{13}$. With a judicious choice of parameters and variables this approach generates a well-specified model which embeds the economic theory and can deliver the parameters of interest ${ }^{14}$.

Given the strong potential for endogeneity of the debt variable, especially reverse causation (low or negative growth rates of per-capita GDP are likely to induce higher debt burdens),

\footnotetext{
12 The estimation results for the basic empirical model are not shown here to save space, but they are available from the authors upon request. As pointed out by an anonymous referee, the use of the three models could be distracting and conflicting.

${ }_{13}$ Phillips (1988) contends that the general-to-specific methodology performs a set of corrections that make it an optimal procedure under weak exogeneity.

${ }_{14}$ An impressive record has been built up for the usefulness of empirical model discovery via general-to-specific searches (see Hendry, 2000).
} 
we use 2SLS (two-stage least squares) instrumental variable techniques to estimate the finally selected model. Following the common practice with macroeconomic data, we use lagged terms of regressors as instruments ${ }^{15}$. Panel A in Table 1 reports the results. It can be observed that all explanatory variables turn out to be significant and their signs are in concordance with the literature. The degree of country's openness to trade, both the proxies used to measure human and physical capital and population growth have a positive impact on real GDP per capita growth, whilst the inflation rate and the ratio of public debt over GDP exert a negative effect ${ }^{16}$.

[Insert Table 1 around here]

The results reported in Panel A in Table 1 support the existence of an asymmetric effect between debt accumulation and debt reduction over growth, since the negative coefficient on the former ( -0.35 on average) is, in absolute values, always higher than the negative coefficient on the latter (-0.16 on average), suggesting that the negative marginal effect of an increase in debt exceeds the positive marginal impact of a debt relief ${ }^{17}$. However, this asymmetric effect clearly differs between countries. The difference between the two marginal impacts ranges from a value of -0.46 in the case of Ireland to one of -0.03 in the case of Finland; Ireland, France, Germany, Portugal and Belgium are the countries where the asymmetry is higher. Interestingly, we do not find clear differences in patterns between central and peripheral countries, since the decrease in the absolute value of the marginal impact in the case of debt reduction varies within each group of countries and its average is -0.2 in both cases.

As can be seen in Panel B in Table 1, the estimated models seem to pass diagnostic tests such as normality of error term, second-order residual autocorrelation and heteroskedasticity $\left(\chi_{2}{ }^{\mathrm{N}}, \chi_{2}{ }^{\mathrm{SC}}\right.$ and $\chi_{2}{ }^{\mathrm{H}}$ respectively). The overall regression fit is satisfactory, as measured by the adjusted $\mathrm{R}^{2}$ value (ranging from 0.5069 for Austria to 0.6991 for Spain).

Finally, if we focus on the marginal impact of a debt reduction over growth in peripheral countries - where some countries (Portugal, Ireland and Greece) received financial rescue packages conditional on fiscal austerity and the implementation of structural reforms, and

\footnotetext{
${ }^{15}$ Following the usual practice, to test whether lagged variables are relevant and valid instrument, we initially examine the first-stage regression, checking sign, significance and plausible magnitude of the coefficients on the instrument. Given the "weak instrument" problem, we apply the "rule of thumb" of a t-stats bigger than 2 (at least 10). We then examine the "reduced form" regression, checking that for the sign and magnitudes of coefficients. Finally, since we have more than one instrument, we test validity/exclusion restrictions using the Sargan (1958)'s test.

16 As pointed out in Section 4.1, a positive effect was expected for the variables measuring openness to trade and physical capital, while a negative effect was expected for the ratio of public debt. However, according to the literature the expected effect of human capital, population growth and inflation rate might either be positive or negative.

${ }^{17}$ Note that an estimated negative coefficient for $\Delta d_{t} I\left(\Delta d_{t}<0\right)$ suggests a positive impact on growth, since such negative coefficient is multiplied by a negative number.
} 
others (Spain) received financial assistance to recapitalize its banks with conditions on implementing structural reforms -, we see that, precisely in these four countries, this impact presents very low values $(-0.18,-0.10,-0.05$ and -0.05 in Portugal, Ireland, Greece and Spain, respectively), highlighting that the effect of austerity policies for boosting economy in those countries is limited.

These results are in accordance with most of the recent literature which has studied whether the consolidation of public finances in the euro area through the reduction of fiscal expenditures and an increase in taxes contributed to GDP growth. Dreger and Reimers (2016) point out that the lack of public investment may have restricted private investment and thus GDP growth. Fatás and Summers (2016) provide support for the presence of strong hysteresis effects of fiscal policy, suggesting that attempts to reduce debt via fiscal consolidations have very likely resulted in a higher debt-to-GDP ratio through their long-term negative impact on output. Jordà and Taylor (2016)'s estimates indicate that in a slump austerity generally prolongs the pain, much more so than in a boom.

Some of the literature has focused its analysis on the peripheral countries hit harder by the crisis. Aldici et al. (2016) look at the feasibility of the fiscal adjustment comparing the macroeconomic conditions in each country and emphasizing the role of the fiscal multipliers in the process. Their results also point to the slump in investment as the key negative factor behind the collapse in demand in all cases. Moreover, they suggest that one of the reasons why the recession was particularly deep in Greece was that the fall in investment was not even partially offset by higher exports, in contrast to Portugal and Ireland. Anderson et al. (2014) contend that structural reforms in core countries could be expected to offset the near-term negative impact on activity arising from the required fiscal consolidation. However, for the periphery, their results suggest that it would take several years before structural reforms could return the level of output to its pre-consolidation path. Inspecting the adjustment programs in place during the past few years in Portugal, Reis (2015) concludes that if success is assessed as making another debt crisis unlikely in the near future, the program delivered; however, if instead it is judged in terms of a rebound of the economy from its prolonged depression, then there is little to celebrate. Finally, Rosnick and Weisbrot (2015), who focus on the Spanish economy, find that the data do not support the thesis that the current economic recovery is the result of a return of market, consumer, and investor confidence due to fiscal consolidation; for them, a more likely explanation is a slowdown and possibly even the end of fiscal consolidation, 
combined with more favourable external factors. These authors corroborate our results that fiscal consolidation in Ireland, Greece, Portugal and Spain barely affected economic recovery.

\subsection{Identifying threshold effects}

Identifying a threshold effect for each economy under study would inform policy makers of the presence of a country-specific tipping point, which would be useful information for guiding macroeconomic policies and fiscal adjustments. To this end, we use the following alternative specification:

$$
\begin{aligned}
& g_{t}=\phi g_{t-1}+\delta_{1} I N F_{t}+\delta_{2} \Delta H K_{t}+\delta_{3} \Delta O P E N_{t}+\delta_{4} P O P G R_{t}+\delta_{5} G C F_{t} \\
& +\gamma_{1} \Delta d_{t} I\left(d_{t} \leq d^{*}\right)+\gamma_{2} \Delta d_{t} I\left(d_{t}>d^{*}\right)+\varepsilon_{t}
\end{aligned}
$$

where $I$ is an indicator function that takes the value 1 if the condition is fulfilled (i. e., if $d_{t}$ is either below or above a specific threshold value $d^{*}$ ) and zero otherwise ${ }^{18}$. Again, the indicator function has the effect of splitting the debt change variable into two, allowing for its impact to differ depending on whether de debt ratio is below or above a given tipping point.

Following the common practice in the empirical literature, the assignment to one or the other regime is determined by the debt-to-GDP ratio, allowing us to compare our results with previous papers which have adopted this ratio as the primary variable of interest. We evaluate all possible values for $d^{*}$, selecting for each country the value that minimizes the sum of squared residuals from the regression as the relevant one ${ }^{19}$.

[Insert Table 2 around here]

We apply the 2SLS estimator proposed by Caner and Hansen (2004) using lagged terms of regressors as instruments. The results in Panel $\mathrm{A}$ in Table 2 show the debt-to-GDP threshold beyond which a debt increase starts to be detrimental for growth. It is striking that we do not find a common debt threshold in the EMU countries under study: it differs notably from country to country, ranging from $61 \%$ in Belgium to $21 \%$ in France. Furthermore, with the exceptions of Belgium (61\%) and Germany (55\%), the average value of the debt threshold is higher in peripheral (48\%) than in central countries (41\%). However, the average negative marginal impact of a debt increase beyond that point on

\footnotetext{
18 Cecchetti et al. (2011) and Baum et al. (2013), among others, use the same indicator function to capture thresholds effects.

19 We also explored the possibility of multiple thresholds, but the data was unable to identify a second significant threshold during the sample period.
} 
growth is much higher in central (-0.59) than in peripheral countries $(-0.24)$. Therefore, these results suggest that with the exceptions of Belgium and Germany, peripheral countries have a little more room to increase their public indebtedness than central ones before it starts to have a detrimental effect on growth. Furthermore, beyond the tipping point the harmful effect of a debt increase on economic performance is much higher in central than in peripheral countries which may explain "the debt intolerance" exhibited by some core EMU countries ${ }^{20}$.

All in all, the average threshold (44\%) for the eleven countries under study is much lower than the figure obtained in the literature for euro area countries by means of panel data techniques. Checherita-Westphal and Rother (2012) find that, between 1970 and 2008, the turning point was $90-100 \%$ of GDP, while Baum et al. (2013), who focused on the 19902010 period, detected a similar threshold (95\%) using a dynamic approach. The different results should be assessed with due caution and should be examined in the context of the distinct methodological approach implemented in this paper, since we adopt a times series analysis instead of a panel data approach and we deal appropriately with the different order of integration of the relevant variables, using changes in debt-to-GDP ratio as the primary variable of interest.

However, in our view, our results are much more consistent than the ones just mentioned with the Stability and Growth Pact's (SGP) ${ }^{21}$ debt ceiling of $60 \%$ of GDP. Otherwise, if the tipping point (beyond which government debt negatively affects growth) was $90-100 \%$ of GDP, what would be the justification for requiring governments, under penalty of fines, to reduce their debt ratios if they surpassed the $60 \%$ reference value? Still, the accuracy of the fiscal limits included in the SGP has been surrounded by considerable controversy in the literature, and there is no agreement on its efficiency.

In an empirical study of whether it pays off (in terms of economic growth) to fulfil the convergence criteria on the public budget and participation in the euro area, Bökemeier and Clemens (2016)'s results show that growth is higher if the debt-to-GDP ratio is below $60 \%$. Similarly, Checherita-Westphal et al. (2014) estimate that euro area governments should maintain a debt-to-GDP target of 50\% if they wish to maximize growth. However, other

\footnotetext{
20 As can be seen in Panel B in Table 2, the regressions fit reasonably well, as they pass the diagnostic tests against nonnormal errors, autocorrelation and heteroskedasticity.

21 The revised Stability and Growth Pact (European Economy, 2011) includes the clause that if the fiscal position falls short of the Medium-Term Objectives (MTOs), countries must implement more ambitious adjustment plans in order to meet them. In addition, for countries with debt ratios above $60 \%$ of GDP, an excessive deficit procedure can be launched if the debt ratio is deemed not to be decreasing at a satisfactory rate - meaning that the debt ratio must diminish annually by at least $1 / 20$ th of the difference between the actual debt ratio and $60 \%$ of GDP reference value.
} 
authors consider that a profound reform of the SGP is needed to make it work in the future. Ioannou and Stracca (2014) present evidence that the SGP has had no significant beneficial impact on the fiscal and economic performance of euro area countries; while Teulings (2016) shows that an episode of increased dynamic inefficiency, like the one driven by the Great Recession and the increased financial volatility, would require a higher debt level than those considered in the SGP.

In this context, the conclusions that can be drawn from our analysis at this point are also mixed. On the one hand, in all the countries under study but Belgium, a debt increase begins to have detrimental effects on growth well before the SGP debt ceiling, meaning that fiscal policies should stay within a safe zone (i.e., a debt ratio of around $50 \%$ and $40 \%$ in peripheral and central countries respectively) below the official fiscal limit. So, with average debt levels of $100 \%$ in euro area countries, deleverage (austerity policies) should be applied; but, according to our results, debt reduction exerts barely any significant beneficial impact on euro area countries' economic performance. Therefore, in our view, adjustment programmes should be accompanied by structural reforms that might increase the adjustment capacity or the potential GDP in euro area countries (see Aldici et. al. 2016). Otherwise, after years of experience with fiscal austerity which have reaffirmed its ineffectiveness as a primary instrument of debt reduction, according to other authors (see Mody (2013), among them) the current policy dilemmas might only be solved in a framework that allows orderly debt restructuring.

Finally, it is interesting to note that in eight out of the 11 countries in our sample (Austria, Finland, France, Germany, Greece, Ireland, Portugal and Spain), the years when the detected thresholds ratios are recorded coincide with the minimum value of the index of the fiscal stance proposed by Polito and Wickens (2012, 2014). This suggests that after a severe worsening of fiscal policy, an additional increase in the debt-to-GDP ratio would not stimulate economic growth. This reading is consistent with the claim made in Polito and Wickens (2012) that the main causes of fluctuations in their index are variations in the gap between expenditures and revenues.

\subsection{Comparing results}

In order to compare the results obtained from the asymmetric model and the threshold model, we perform stochastic dynamic simulations of the estimated models to assess how each explanatory variable contributes to the explanation of the average growth rate of real 
per capita GDP during the 1981-2015 period. Table 3 reports the results for each country under study ${ }^{22}$.

\section{[Insert Table 3 around here]}

As can be seen, the absolute value of the average negative contribution of a debt increase to growth is similar (-0.2) in the asymmetric and the threshold model. However, while in the asymmetric model the average negative contribution is somewhat higher in central countries (-0.3) rather than in peripheral ones $(-0.2)$, in the threshold model the average negative contribution does not change between the two groups of countries.

To compare the two models further, we perform dynamic multi-step forecasts of $g_{t}$ within the sample using previously forecasted values of $g_{t}$, and evaluate these forecasts based upon the model with the actual data. Table 4 shows the forecasting performance of our competing models. We evaluated their forecasting performance using five different measures of forecast accuracy: The Root Mean Squared Error (RMSE), the Mean Absolute Error (MAE), the Mean Absolute Percentage Error (MAPE), and two Theil Inequality coefficients ( $\mathrm{U}_{1}$ for forecast accuracy and $\mathrm{U}_{2}$ for forecast quality). These statistics all provide a measure of the distance of the true from the forecasted values.

\section{[Insert Table 4 around here]}

The results presented in Table 4 indicate that in most of the countries the threshold model reports higher forecast accuracy. The exceptions are Austria, Italy, and the Netherlands, where the asymmetric model presents better forecast quality jointly with Germany and Finland, where both the threshold and the asymmetric model seem to be just as good.

Therefore, when analyzing the contribution of a debt increase in economic growth (Table 3), we will rely on the results obtained from the threshold model in the case of Belgium, France, Greece, Ireland, Portugal and Spain; while in Austria, Italy and the Netherlands, we will use the results from the asymmetric model. In the case of Germany and Finland, we will take both into account. In Finland, the negative contribution of a debt increase to growth is very similar in both models (-0.18 and -0.20). However, in Germany, in absolute terms, the contribution is higher in the asymmetric model $(-0.45)$ rather than in the threshold one (-0.22). Therefore, the average negative contribution of a debt increase in euro area countries economic performance is slightly higher when using the value from the asymmetric model in these two countries $(-0.3$ compared to -0.2 , if the value from the

${ }^{22}$ To save space, we only comment on the results for variations in the debt-to-GDP ratio. 
threshold model is used). Moreover, while the average negative contribution of a debt increase in euro peripheral countries' growth is -0.2 , it ranges from -0.25 until -0.29 in central countries depending on the value used in Finland and Germany.

Focusing on the behaviour of the contribution of a debt increase to economic growth within each group of countries (central and peripheral), we do find important differences. France, Germany, Belgium and Finland are the central countries with the highest negative contribution of a debt increase (their values range from -0.85 to -0.2), while the Netherlands and Austria have the lowest (-0.02 and -0.005 respectively). In the case of peripheral countries, Ireland, Italy and Portugal are the ones with the highest negative contribution $(-0.34,-0.34$ and -0.18$)$, while in Greece and Spain it is significantly lower (0.10 and -0.06 respectively).

Even though we agree that it is imperative to lower public debt over time, these results, combined with those displayed in Table 1, reinforce the idea that European policymakers need to be aware that the effect of debt on economic performance differs according to EMU country, as does the effect of fiscal adjustments on growth prospects. Therefore, we think that the pace of adjustment should differ between countries. In particular, according to our results, the five peripheral countries under study should be split in three groups with regard to the implementation of policy measures. The first would include Spain and Greece, Portugal would be the sole member of the second, and the third group might be formed by Italy and Ireland.

In Spain and Greece, not only is the debt threshold above 50\% (close to $60 \%$ in the Greek case), but the negative contribution of a debt increase to economic growth is also very low. In Portugal public debt reaches its tipping point at a lower value (close to $40 \%$ ) but the negative contribution of higher sovereign indebtedness to economic performance is still small (-0.18). Finally, in Italy and Ireland the debt threshold ranges from $40 \%$ to $50 \%$ and the negative contribution of a debt increase is high (-0.34).

Consequently, in the Greek and Spanish cases (whose economies have been severely hit by the crisis), our findings suggest that the pace of fiscal adjustment should be lower than in the other three countries. However, in Ireland and Italy (the countries with the highest detrimental effect of a sovereign debt increase on growth) a faster fiscal adjustment should be applied. Besides, in order to support growth when fiscal policy is tightened, we also agree that there is a need for reforms in goods, service, and labour markets to improve economic efficiency and boost potential growth, thus serving as important tools in the 
fiscal adjustment process. Policies enhancing both stability and growth are possible in the EMU; some of them have already been implemented, and others are at an advanced stage of development.

\subsection{Robustness check ${ }^{23}$}

Given that the sample period includes the inception of the EMU in January 1999, we conduct robustness checks by splitting the sample before and during EMU in order to examine whether the introduction of the fiscal discipline rules that came along with the common currency might have influenced the relationship between a debt change and economic growth from that date. The estimated coefficients for a debt change in the two periods corresponding to the asymmetric and the threshold model are shown in Tables 5 and 6 , respectively.

\section{[Insert Tables 5 and 6 around here]}

The estimation results shown in these tables remain robust across both models, being once again the coefficients on debt variations statistically significant with the same sign, confirming the presence of asymmetric and threshold effects before and during the EMU.

As can be seen in Table 5, when we compare the marginal impact on growth of debt accumulation and relief, before and after the beginning of the monetary union, the Wald test of significant differences in the estimated coefficients shows that the null hypothesis of no difference between pre-EMU and EMU coefficients associated with debt accumulation $\left(\hat{\beta}_{1}\right)$ is rejected at the $1 \%$ significance level in Germany and at the $10 \%$ significance level in Ireland and the Netherlands, while there is no statistically significant difference between pre-EMU and EMU coefficients associated with debt relief $\left(\hat{\beta}_{2}\right)$ except for Ireland and Italy (at the 5\% significance level), and for Finland (at the 10\% significance level).

Moreover, in all the above cases but Ireland, the marginal impact of a debt change decreases with the introduction of the euro, suggesting that the fiscal discipline associated with the Stability and Growth Pact and the Excessive Deficit Procedure had somewhat mitigated the capacity of fiscal policies to influence economic growth. As said, Ireland seems to be an exception since the negative effect of a debt accumulation on economic growth is higher during the EMU period than before the introduction of the common currency.

23 We are grateful to an anonymous referee for suggesting this analysis. 
Regarding the threshold model $^{24}$, the Wald tests in Table 6 indicate that the marginal impact of a debt change on economic growth is only statistically different in the two periods at the $10 \%$ level in Germany above the determined tipping point (55\% which is reached in 1995). Concretely, in that country, again the negative marginal impact of a debt increase beyond the threshold decreases with the introduction of the euro.

All in all, the results from this robustness check suggest that the fiscal discipline and the multilateral surveillance of budget positions that were introduced with the inception of the EMU have moderated the impact of fiscal policies on economic growth, but only to some extent [as contend by Ioannou and Stracca (2014) or Teulings (2016), among others], since the coefficient estimates of both asymmetric and threshold models do not reveal statistically significant differences for most of the countries under study, given further support to the findings in the previous sub-sections.

\section{Concluding remarks}

In this paper, we propose a new approach to analyse the debt-growth nexus, a relationship which has spawned a multitude of studies using a wide range of methodologies and conclusions. The previous work rests largely on the results from panel data studies, but we argue that more can be learned from appropriate time series analyses for individual countries in order to record their heterogeneous experiences. In doing so, we do not discount the importance of the panel data approach, which has some relevant theoretical implications; rather, we question the way in which these results are presented, and indeed the way in which they are used by policymakers.

Therefore, this paper builds upon the existing literature studying the effect of public debtto-GDP ratio on economic growth, focusing on the time series dimension of the issue to obtain further evidence based on the historical experience of 11 EMU member countries during the 1961-2015 period to detect potential heterogeneities in the relationship across the euro area. As in every empirical analysis, the results must be treated with some caution since they are based on a set of countries over a certain period and on a given econometric methodology. This is particularly true of the comparison of the results with those of previous papers, since we adopt a time series analysis instead of a panel data approach, and

\footnotetext{
${ }^{24}$ Note that, during the EMU subsample, only for Ireland and Spain there are observations where the debt-to-GDP ratio is below the estimated threshold $\left(d_{t} \leq d^{*}\right)$. Therefore, we can only test the null hypothesis $\hat{\gamma}_{1}^{\text {Pre-EMU }}=\hat{\gamma}_{1}^{\text {EMU }}$ for these two countries.
} 
since we use changes in debt-to-GDP ratio as the primary variable of interest instead of the level of debt-to-GDP ratio ${ }^{25}$.

The results presented in this paper should be of value to macro-prudential policymakers, as they provide evidence that in all the countries under study (with the exception of Belgium) a debt increase begins to have detrimental effects on growth well before the SGP debt ceiling is reached, meaning that fiscal policies should stay within a safe zone (a debt ratio around $40 \%$ and $50 \%$ in central and peripheral countries respectively) below the official fiscal limit. So, with average debt levels of $100 \%$ in euro area countries, deleverage (austerity policies) should be applied, but according to our results debt reduction does not exert any significant benefit on euro area countries' economic performance. Therefore, in our view, adjustment programmes should be accompanied by structural reforms able to increase the adjustment capacity or the potential GDP in euro area countries. Otherwise, the current policy dilemmas might only be solved (see Mody, 2013) in a framework that allows orderly debt restructuring.

Moreover, since our results provide support for the idea that the harmful impact of debt on growth does not occur beyond the same debt ratio threshold and with the same intensity in all EMU countries, a focus on average ratios and impacts may be misleading for the definition of policy in individual countries. This is especially true in an environment in which some EMU countries must already apply adjustment plans that re-establish competitiveness and fiscal balance. Specifically, our findings suggest that the pace of fiscal adjustment should be lower in Greece and Spain than in the other three peripheral countries.

Finally, our findings may also provide useful inputs for further research since, as Coase $(1988,71)$ states "the inspiration is most likely to come through the stimulus provided by the patterns, puzzles and anomalies revealed by the systematic gathering of data, particularly when the prime need is to break our existing habits of thought". Concretely, in view of the encouraging results of the present study, an extension of the present research might explore which are the channels (e.g., the equilibrium real interest rate, the sovereign risk premium or the expected future tax rates, among them) that drive the debt-growth relationship. Although this analysis is beyond the scope of the present paper, due to its relevance, it is in our near future research agenda.

\footnotetext{
25 To the best of our knowledge, there is no any previous study which has yet examined the statistical property of the public debt-to-GDP ratio series and taken into consideration its stationarity property in the analysis of the debt-growth nexus.
} 


\section{Acknowledgements}

The authors wish to thank two anonymous referees for their helpful comments and suggestions on a previous draft of this article, which have enabled us to introduce substantial improvements. The paper has also benefited from discussion with Christopher Martin, Bruce Morley, Vanja Piljak, Nikolaos Sakkas and the participants at the First Catalan Economic Society Conference in Barcelona and the 15th INFINITI Conference on International Finance in Valencia. Simón Sosvilla-Rivero thanks the Department of Economics for their hospitality during a research visit at the University of Bath. Responsibility for any remaining errors rests with the authors.

\section{Funding}

This paper is based upon work supported by the Instituto de Estudios Fiscales [grant IEF 015/2017], the Bank of Spain [grant PR71/15-20229], the Spanish Ministry of Education, Culture and Sport [grant PRX16/00261] and the Spanish Ministry of Economy and Competitiveness [grant ECO2016-76203-C2-2-P]. 


\section{References}

Aizenman, J., Kletzer, K., Pinto B. 2007. Economic growth with constraints on tax revenues and public debt: Implications for fiscal policy and cross-country differences. Working Paper 12750, National Bureau of Economic Research, Cambridge, MA.

Aldici, C., Belke, A., Giovannini, A., Gros, D. 2016. Macroeconomic adjustment programmes in the euro area: An overall assessment. International Economics and Economic Policy 13, 345-358.

Alesina, A.; Ardagna, S. 2010. Large changes in fiscal policy: taxes versus spending. In Jeffrey R. Brown (Ed.) Tax Policy and the Economy, Vol. 24. University of Chicago Press, Chicago (pp. 35-68).

Alesina, A., Barbiero, O., Favero, C., Giavazzi, F., Paradisi, M. 2015. Austerity in 20092013. Working Paper 20827, National Bureau of Economic Research, Cambridge, MA.

Alogoskoufis, G. 2012. Greece's sovereign debt crisis: retrospect and prospect. GreeSE Paper 54. Hellenic Observatory, London School of Economics and Political Science, London.

Anderson, D., Hunt, B., Snudden, S. 2014. Fiscal consolidation in the euro area: How much pain can structural reforms ease? Journal of Policy Modeling 36, 785-799.

Antonakakis, N. 2014. Sovereign debt and economic growth revisited: The role of (non-) sustainable debt thresholds. Working Paper 187, Department of Economics, University, Vienna, Vienna.

Asimakopoulos, S., Karavias, Y. 2016. The impact of government size on economic growth: A threshold analysis. Economics Letters 139, 65-68

Barro, R. J. 1990. Government spending in a simple model of endogenous growth. Journal of Political Economy 98, S103-S125.

Barro, R. J. 2003. Determinants of economic growth in a panel of countries. Annals of Economics and Finance 4, 231-274.

Barro, R., Lee, J.-W. 2013. A new data set of educational attainment in the world, 19502010. Journal of Development Economics 104, 184-198.

Barro, R. B. and Sala-i-Martin, X. 1995. Economic growth, The MIT Press, Cambridge MA.

Barro, R. B. and Sala-i-Martin, X. 2004. Economic growth, 2nd ed. The MIT Press, Cambridge MA.

Baum, A., Checherita-Westphal, C. and Rother, P. 2013. Debt and growth: New evidence for the euro area. Journal of International Money and Finance 32, 809-821.

Becker, G. S. 2007. Health as human capital: Synthesis and extensions. Oxford Economic Papers 59, 379-410.

Bökemeier, B., Clemens, C. 2016. Does it pay to fulfill the Maastricht convergence criteria? Reflections on the public debt and growth nexus for selected European economies. Working Paper in Economics and Management 10. Bielefeld University, Germany.

Bruno, M., Easterly, W. 1998. Inflation crises and long-run growth. Journal of Monetary Economics 41 3-26.

Caner, M., Hansen, B. 2004. Instrumental variable estimation of a threshold model. Econometric Theory 20, 813-843.

Cecchetti, S. G., Mohanty, M., Zampolli, F. 2011. The real effects of debt. In: Economic Symposium Conference Proceedings. Federal Reserve Bank of Kansas City, 145-196.

Center for Economic Policy Research. 2014. Euro area business cycle dating committee: Euro area mired in recession pause. Centre for Economic Policy Research, London. 
Checherita-Westphal, C., Rother, P. 2012. The impact of high government debt on economic growth and its channels: An empirical investigation for the euro area. European Economic Review 56, 1392-1405.

Checherita-Westphal, C., Hallett, A.H., Rother, P. 2014. Fiscal sustainability using growthmaximizing debt targets. Applied Economics 46, 638-647.

Cheung, Y.-W., Chinn, M. D., 1997. Further investigation of the uncertain unit root in GNP. Journal of Business and Economic Statistics 15, 68-73.

Chow, G. C. 1960. Tests of equality between sets of coefficients in two linear regressions. Econometrica 28, 591-605.

Chudik, A., Mohaddes, Pesaran, K., Raissi, M. 2017. Is there a debt-threshold effect on output growth? Review of Economics and Statistics, forthcoming.

Coase, R. H. 1988. The firm, the market and the law. Chicago University Press, Chicago.

Cochrane, J.H. 2011. Understanding policy in the great recession: Some unpleasant fiscal arithmetic. European Economic Review 55, 2-30.

Corsetti, G., Roubini, N. 1991. Fiscal deficits, public debt and government solvency: Evidence from OECD countries. Journal of the Japanese and International Economies 5, 354-380.

Cottarelli, C., Jaramillo, L. 2013. Walking hand in hand: Fiscal policy and growth in advanced economies. Review of Economics and Institutions 4, 1-25.

De Gregorio, J. 1993. Inflation, taxation, and long-run growth. Journal of Monetary Economics 31, 271-298.

Delong, B.J., Summers, L.H. 2012. Fiscal policy in a depressed economy. Brookings Papers on Economic Activity (Spring), 233-274.

Doornik, J. A., Hendry, D.F. 2015. Statistical model selection with big data. Cogent Economics and Finance, DOI:10.1080/23322039.2015.1045216.

Dotsey, M., Sarte, P.D. 2000. Inflation uncertainty and growth in a cash-in-advance economy. Journal of Monetary Economics 45, 631-655.

Dreger, C., Reimers, H.E. 2013. Does euro area membership affect the relation between GDP growth and public debt? Journal of Macroeconomics 38, 481-486.

Dreger, C., Reimers, H.E. 2016. Does public investment stimulate private investment? Evidence for the euro area. Economic Modelling 58, 154-158.

Eberhardt, M., Presbitero, A.F. 2015. Public debt and growth: Heterogeneity and nonlinearity. Journal of International Economics 97, 45-58.

Edwards, S. 1998. Openness, productivity and growth. Economic Journal 108, 383-398.

Elliott, G., Rothenberg, T. J., Stock, J.H. 1996. Efficient tests for an autoregressive unit root, Econometrica 64, 813-836.

Elmendorf, D., Mankiw, N.G. 1999. Government debt. In J. B. Taylor and M. Woodford (Eds), Handbook of Macroeconomics, Vol. 1C. North-Holland, Amsterdam (pp. 16151669).

Égert, B. 2015. The 90\% public debt threshold: the rise and fall of a stylized fact. Applied Economics 47, 3756-3770.

European Commission. 1995. The impact of exchange-rate movements on trade within the Single Market. European Economy 4, 1-94.

European Economy. 2011. Public finances in EMU-2011, European Economy, 3/2011, DGII (EcFin), European Commission, Brussels, September 
Fatás, A., Summers, L.H. 2016. The permanent effects of fiscal consolidations. Working Paper 22474, National Bureau of Economic Research, Cambridge, MA.

Faust. J., Whiteman, C.H. 1997. General-to-specific procedures for fitting a dataadmissible, theory-inspired, congruent, parsimonious, encompassing, weakly exogenous, identified, structural model to the DGP: A translation and critique, International Finance Discussion Papers 1997-576, Board of Governors of the Federal Reserve System, Washington D.C.

Feenstra, R. C., Inklaar, R., Timmer, M.P. 2013. The next generation of the Penn World Table, available for download at www.ggdc.net/pwt

Fischer, S. 1993. The role of macroeconomic factors in growth. Journal of Monetary Economics 32, 485-512.

Frankel, M. 1962. The production function in allocation and growth: A synthesis. American Economic Review 52, 996-1022.

Friedman, M. 1977. Nobel lecture: Inflation and unemployment. Journal of Political Economy 85, 451-472.

Ghosh, A. R., Kim, J.I., Mendoza, E. G., Ostry, J.D., Qureshi, M.S. 2013. Fiscal fatigue, fiscal space and debt sustainability in advanced economies. The Economic Journal 123, F4-F30.

Gómez-Puig, M., Sosvilla-Rivero, S. 2015. The causal relationship between debt and growth in EMU countries. Journal of Policy Modeling 37, 974-989.

Granger, C.W.J. 1990. Where are the controversies in econometric methodology? in Granger, C.W.J. (Ed.) Modelling economic time series: Reading in econometric methodology. Oxford University Press, Oxford (pp. 1-23).

Guajardo, J., Leigh, D., Pescatori. A. 2011. Expansionary austerity: New international evidence. Working Paper 11/158, International Monetary Fund, Washington D. C.

Greiner, A. 2014. Public debt and the dynamics of economic growth. Annals of Economics and Finance 15, 185-204.

Grossman, G., Helpman, E. 1991. Innovation and growth in the global economy. Cambridge, Massachusetts: MIT Press.

Hendry, D.F. 1995. Dynamic econometrics. Oxford University Press, Oxford.

Hendry, D.F. 2000. Epilogue: The success of general-to-specific model selection. In Econometrics: Alchemy or Science? Oxford University Press, Oxford (pp. 467-490).

Hicks, J.R. 1981. Wealth and welfare. Collected essays on economic theory, Vol. I. Basil Blackwell, Oxford.

Ioannou, D., Stracca, L. 2016. Have the euro area and EU governance worked? Just the facts. European Journal of Political Economy 34, 1-17.

Jacquemin, A., Sapir, A. 1996. Is a European hard core credible? A statistical analysis. Kyklos 49, 105- 117.

Jayachandran, S., Lleras-Muney, A. 2009. Life expectancy and human capital investments: Evidence from maternal mortality declines. Quarterly Journal of Economics 124, 349-397.

Jordà, O., Taylor, A.M. 2016. The time for austerity: Estimating the average treatment effect of fiscal policy. The Economic Journal 126, 219-255.

Keynes, J. M. 1936. The general theory of employment, interest and money. Macmillan, London.

Kwiatkowski, D., Phillips, P.C.B, Schmidt, P., Shin, Y. 1992. Testing the null hypothesis of stationary against the alternative of a unit root. Journal of Econometrics 54, 159-178. 
Ledesma-Rodríguez, F., Navarro-Ibáñez, M., Pérez-Rodríguez, J., Sosvilla-Rivero, S. 2005. Assessing the credibility of a target zone: Evidence from the EMS. Applied Economics 37, 2265-2287.

Levine, R., Renelt, D. 1992. A sensitivity analysis of cross-country growth regressions. American Economic Review 82, 942-963.

Lof, M., Malinen, T. 2014. Does sovereign debt weaken economic growth? A panel VAR analysis. Economics Letters 122, 403-407.

Mankiw, N. G., Romer, D., Weil, D.N. 1992. A contribution to the empirics of economic growth. Quarterly Journal of Economics 107, 407-437.

Markus, A., Rainer, S. 2016. Public debt and economic growth: Economic systems matter, Discussion Paper 281, Center for European Governance and Economic Development Research, Göttingen.

Mitze, T., Matz, F. 2015. Public debt and growth in German federal states: What can Europe learn? Journal of Policy Modeling 37, 208-228.

Mody, A. 2013. Sovereign debt and its restructuring framework in the Eurozone. Oxford Review of Economic Policy 29, 715-744.

Newey, W.K., West, K.D. 1987. A simple, positive semi-definite, heteroskedasticity and autocorrelation consistent covariance matrix. Econometrica 55, 703-708.

Ng, S., Perron, P. 2001. Lag length selection and the construction of unit root tests with good size and power. Econometrica 69, 1519-1554.

Panizza, U., Presbitero, A. 2013. Public debt and economic growth in advanced economies: A survey. Swiss Journal of Economics and Finance 149, 175-204.

Pattillo, C., Poirson, H., Ricci, L.A. 2011. External debt and growth. Review of Economics and Institutions 2, 1-30.

Perotti, R. 2012. The "austerity myth" gain without pain? In Fiscal policy after the financial crisis, NBER Chapters. National Bureau of Economic Research, Cambridge, MA.

Pescatori, A., Sandri, D., Simon, J. 2014. Debt and growth: Is there a magic threshold? Working Paper 14/34, International Monetary Fund, Washington D. C.

Phillips, P.C.B. 1988. Reflections on econometric methodology. Economic Record 64, 344-359.

Phillips, P.C.B., Perron, P. 1988. Testing for a unit root in time series regression. Biometrika 75, 335-346

Polito, V., Wickens, M. 2014. A model-based indicator of the fiscal stance. European Economic Review 56, 526-551.

Polito, V., Wickens, M. 2014. How the euro crisis evolved and how to avoid another: EMU, fiscal policy and credit ratings. Journal of Macroeconomics 39, 364-374.

Psacharopoulos, G. 1994. Returns to investment in education: A global update. World Development 22, 1325-1343.

Radelet, S., Sachs, J., Lee, J. 2001. The determinants and prospects of economic growth in Asia. International Economic Journal 15, 1-29.

Reinhart, R., Rogoff, K. 2010. Growth in a time of debt. American Economic Review 100, 573-578.

Reis, R. 2015. Looking for a success: The euro crisis adjustment programs. Discussion Paper 10972, Center for Economic and Policy Research, London.

Romer, P.M. 1992. Two strategies for economic development: Using ideas and producing ideas. World Bank Economic Review 6 (Sup 1), 63-91. 
Rosnick, D., Weisbrot, M. 2015. Has austerity worked in Spain? Center for Economic and Policy Research, London.

Sachs, J.D., Warner, A.W. 1997. Fundamental sources of long-run growth. American Economic Review 87, 184-188.

Salotti, S., Trecroci, C. 2016. The impact of government debt, expenditure and taxes on aggregate investment and productivity growth. Economica 83, 356-384.

Sargan, J. D. 1958. The estimation of economic relationships using instrumental variables. Econometrica 26, 393-415.

Seghezza, E., Baldwin, R.E. 2008. Testing for trade-induced investment-led growth. Economia Internazionale/International Economics 61, 507-537.

Solow, R. M. 1956. A Contribution to the theory of economic growth. Quarterly Journal of Economics 70, 65-94.

Sosvilla-Rivero, S., Morales-Zumaquero, A. 2012. Volatility in EMU sovereign bond yields: Permanent and transitory components. Applied Financial Economics 22, 1453-1464.

Teles, V., Mussolini, C. 2014. Public debt and the limits of fiscal policy to increase economic growth. European Economic Review 66, 1-15.

Teulings, C. 2016. Are bubbles bad? Is a higher debt target for the eurozone desirable? CESifo Economic Studies 62, 197-209.

Tobin, J., 1965. Money and economic growth. Econometrica 33, 671-810

Woo, J., Kumar, M. S. 2015. Public debt and growth. Economica 82, 705-739.

World Bank. 1990. World development report 1990: Poverty. Oxford University Press, New York. 


\section{Appendix 1: Definition of the explanatory variables and data sources}

\begin{tabular}{|c|c|c|}
\hline Variable & Description & Source \\
\hline Real growth rate $\left(g_{t}\right)$ & Growth rate of real per capita GDP (annual \%) & $\begin{array}{c}\text { World Development Indicators (World Bank), } \\
\text { extended to } 2015 \text { using World Economic } \\
\text { Outlook, October } 2016 \text { (IMF) }\end{array}$ \\
\hline Level of Output $\left(y_{t}\right)$ & Per capita Gross domestic product at 2010 market prices & $\begin{array}{l}\text { AMECO, extended to } 2015 \text { using World } \\
\text { Economic Outlook, October } 2016 \text { (IMF) }\end{array}$ \\
\hline Public debt-to-GDP ratio $\left(d_{t}\right)$ & Ratio of net public debt to GDP & AMECO and International Monetary Fund \\
\hline Population growth $\left(P O P G R_{t}\right)$ & Population growth (annual \%) & $\begin{array}{c}\text { World Development Indicators (World Bank), } \\
\text { extended to } 2015 \text { using World Economic } \\
\text { Outlook, October } 2016 \text { (IMF) }\end{array}$ \\
\hline GCF-to-GDP ratio $\left(G C F_{t}\right)$ & Ratio of gross capital formation to GDP & World Development Indicators (World Bank) \\
\hline Human capital $\left(H K_{t}\right)$ & Life expectancy at birth, total (years) & World Development Indicators (World Bank) \\
\hline Openness $\left(O P E N_{t}\right)$ & Absolute sum of exports and imports over GDP & $\begin{array}{c}\text { World Development Indicators (World Bank), } \\
\text { extended to } 2015 \text { using World Economic } \\
\text { Outlook, October } 2016 \text { (IMF) }\end{array}$ \\
\hline Inflation $\left(I N F_{t}\right)$ & Growth rate of GDP deflator (annual \%) & $\begin{array}{c}\text { World Development Indicators (World Bank), } \\
\text { extended to } 2015 \text { using World Economic } \\
\text { Outlook, October } 2016 \text { (IMF) }\end{array}$ \\
\hline
\end{tabular}


Figure 1. Sovereign Debt-to-GDP and GDP per capita growth evolution in EMU countries: 1961-2015

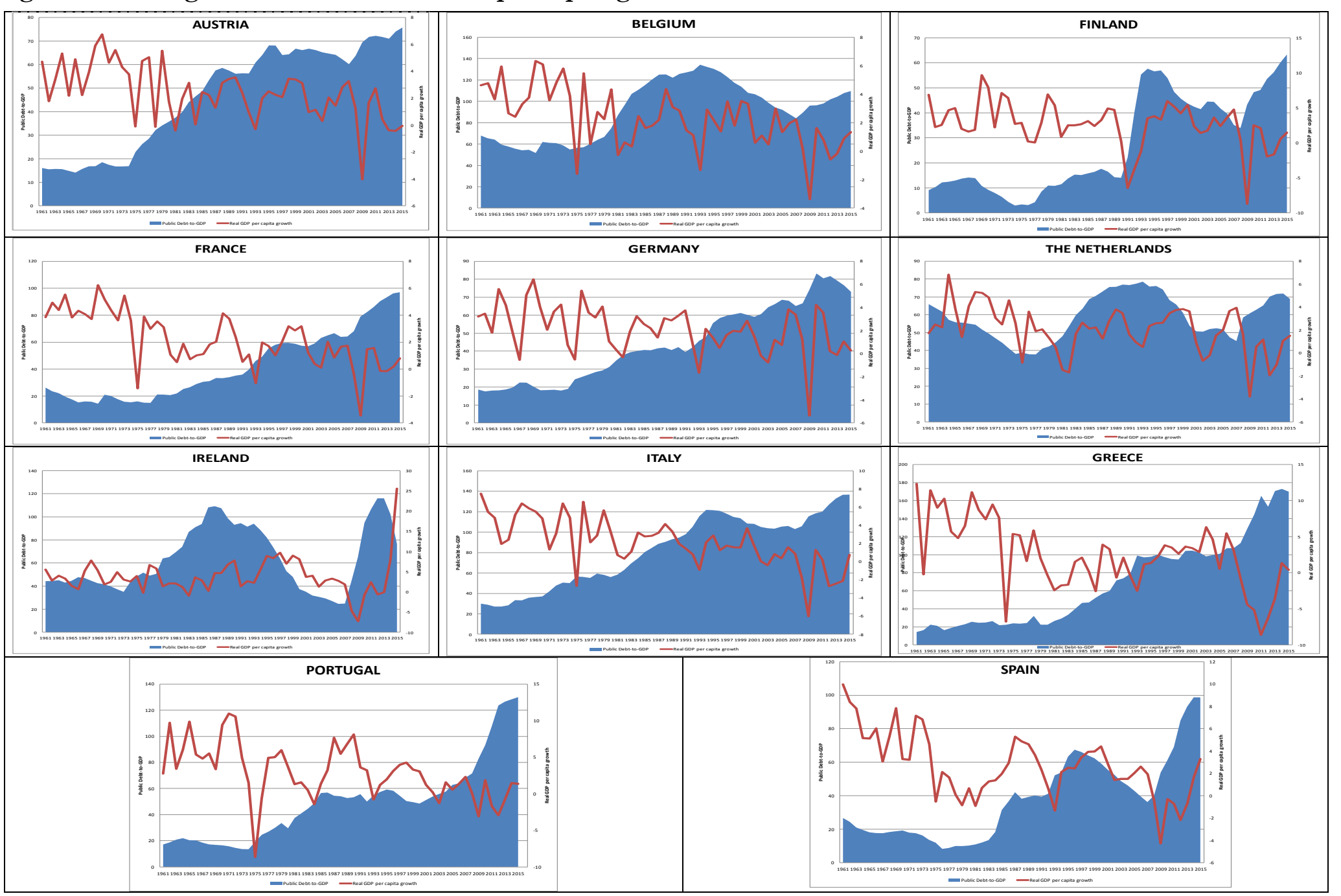

Note. Source AMECO and WDI 
Table 1: Asymmetric model estimation results

\begin{tabular}{|c|c|c|c|c|c|c|c|c|c|c|c|}
\hline \multicolumn{12}{|c|}{ Panel A: Estimation results } \\
\hline & $\mathbf{A T}$ & $\mathbf{B E}$ & FI & FR & GE & GR & IE & IT & NL & PT & SP \\
\hline$g_{t-1}$ & $\begin{array}{l}0.3559^{*} \\
(3.0788)\end{array}$ & $\begin{array}{l}0.1870^{* *} \\
(2.5262)\end{array}$ & $\begin{array}{l}0.1073^{*} \\
(2.8123)\end{array}$ & $\begin{array}{c}0.3912^{*} \\
(3.5921)\end{array}$ & $\begin{array}{c}0.0742^{* *} \\
(2.5679)\end{array}$ & $\begin{array}{c}0.3480^{*} \\
(2.7614)\end{array}$ & $\begin{array}{l}0.2401^{* *} \\
(2.4153)\end{array}$ & $\begin{array}{c}0.3559^{*} \\
(3.0331)\end{array}$ & $\begin{array}{l}0.2898^{* *} \\
(2.3412)\end{array}$ & $\begin{array}{l}0.2708^{* * *} \\
(2.3516)\end{array}$ & $\begin{array}{l}0.6603^{*} \\
(3.0222)\end{array}$ \\
\hline$I N F_{t}$ & $\begin{array}{l}-0.0652^{*} \\
(-2.9961)\end{array}$ & $\begin{array}{l}-0.0106^{\text {** }} \\
(-2.4834)\end{array}$ & $\begin{array}{l}-0.0161^{* *} \\
(-2.3312)\end{array}$ & $\begin{array}{l}-0.0688^{* *} \\
(-2.3550)\end{array}$ & $\begin{array}{l}-0.1253^{* *} \\
(-2.2652)\end{array}$ & $\begin{array}{l}-0.1799^{* *} \\
(-2.6431)\end{array}$ & $\begin{array}{l}-0.1262^{*} \\
(-2.8015)\end{array}$ & $\begin{array}{l}-0.0359^{* *} \\
(-2.3328)\end{array}$ & $\begin{array}{l}-0.0777^{* *} \\
(-2.4357)\end{array}$ & $\begin{array}{l}-0.1074^{* *} \\
(-2.5315)\end{array}$ & $\begin{array}{l}-0.0386^{*} \\
(-2.8881)\end{array}$ \\
\hline$\Delta H K_{t}$ & $\begin{array}{l}1.6174^{* *} \\
(2.3552)\end{array}$ & $\begin{array}{l}0.3891^{\text {** }} \\
(2.4215)\end{array}$ & $\begin{array}{c}0.8188^{*} \\
(2.7420)\end{array}$ & $\begin{array}{c}0.8502^{*} \\
(3.8110)\end{array}$ & $\begin{array}{l}0.5722^{* *} \\
(2.3291)\end{array}$ & $\begin{array}{l}6.0990^{* *} \\
(2.3261)\end{array}$ & $\begin{array}{c}3.1679 \\
(2.3716)\end{array}$ & $\begin{array}{l}0.3697^{* *} \\
(2.4171)\end{array}$ & $\begin{array}{l}0.1124^{* *} \\
(2.3232)\end{array}$ & $\begin{array}{l}1.3625^{* *} \\
(2.4571)\end{array}$ & $\begin{array}{c}0.7463^{*} \\
(2.8221)\end{array}$ \\
\hline$\triangle O P E N_{t}$ & $\begin{array}{l}0.2495^{*} \\
(3.2762)\end{array}$ & $\begin{array}{c}0.1166^{*} \\
(3.4623)\end{array}$ & $\begin{array}{c}0.3001^{*} \\
(3.3361)\end{array}$ & $\begin{array}{c}0.1827^{*} \\
(2.4207)\end{array}$ & $\begin{array}{l}0.3193^{*} \\
(3.9825)\end{array}$ & $\begin{array}{l}0.0679^{* *} \\
(2.4801)\end{array}$ & $\begin{array}{c}0.0347 \\
(2.6916)\end{array}$ & $\begin{array}{c}0.3259^{*} \\
(2.8812)\end{array}$ & $\begin{array}{c}0.0998^{*} \\
(2.8415)\end{array}$ & $\begin{array}{c}0.0652^{*} \\
(2.7661)\end{array}$ & $\begin{array}{l}0.2256^{* *} \\
(2.4551)\end{array}$ \\
\hline POPGROt & $\begin{array}{l}0.8097^{* *} \\
(2.3115)\end{array}$ & $\begin{array}{l}2.2881^{* *} \\
(2.5923)\end{array}$ & $\begin{array}{c}3.1118^{*} \\
(2.7812)\end{array}$ & $\begin{array}{c}0.5730^{*} \\
(2.5134)\end{array}$ & $\begin{array}{c}0.3691^{*} \\
(2.6681)\end{array}$ & $\begin{array}{l}1.5568^{* *} \\
(2.3341)\end{array}$ & $\begin{array}{c}0.1370 \\
(2.3527)\end{array}$ & $\begin{array}{l}1.3890^{* *} \\
(2.3862)\end{array}$ & $\begin{array}{l}1.2397^{* *} \\
(2.3281)\end{array}$ & $\begin{array}{c}1.4770^{*} \\
(2.9188)\end{array}$ & $\begin{array}{l}0.9190^{* *} \\
(2.5662)\end{array}$ \\
\hline$G C F_{t}$ & $\begin{array}{l}0.5343^{* *} \\
(2.4962)\end{array}$ & $\begin{array}{c}0.1312^{*} \\
(3.8324)\end{array}$ & $\begin{array}{c}0.1661^{*} \\
(4.1012)\end{array}$ & $\begin{array}{c}0.0564^{*} \\
(3.2123)\end{array}$ & $\begin{array}{l}0.0755^{* *} \\
(2.4618)\end{array}$ & $\begin{array}{l}0.4923^{* *} \\
(2.3516)\end{array}$ & $\begin{array}{c}0.2046 \\
(2.8801)\end{array}$ & $\begin{array}{c}0.1319^{*} \\
(3.1715)\end{array}$ & $\begin{array}{c}0.7081^{*} \\
(3.2661)\end{array}$ & $\begin{array}{c}0.1396^{*} \\
(4.2320)\end{array}$ & $\begin{array}{l}0.0810^{* *} \\
(2.4617)\end{array}$ \\
\hline$\Delta d_{t} I\left(\Delta d_{t}>0\right)$ & $\begin{array}{l}-0.1457^{* *} \\
(-2.5634)\end{array}$ & $\begin{array}{l}-0.2408^{*} \\
(-2.6921)\end{array}$ & $\begin{array}{l}-0.5437^{*} \\
(-4.5723)\end{array}$ & $\begin{array}{l}-0.6297^{*} \\
(-2.5815)\end{array}$ & $\begin{array}{l}-0.4169^{* *} \\
(-3.3752)\end{array}$ & $\begin{array}{l}-0.1010^{* *} \\
(-2.5171)\end{array}$ & $\begin{array}{c}-0.5607 \\
(-4.7312)\end{array}$ & $\begin{array}{c}-0.4481^{*} \\
(-2.7143)\end{array}$ & $\begin{array}{l}-0.2516^{*} \\
(-2.6661)\end{array}$ & $\begin{array}{l}-0.3996^{*} \\
(-3.7512)\end{array}$ & $\begin{array}{l}-0.1507^{* *} \\
(-2.5810)\end{array}$ \\
\hline$\Delta d_{t} I\left(\Delta d_{t}<0\right)$ & $\begin{array}{l}-0.0864^{* *} \\
(-2.3998)\end{array}$ & $\begin{array}{l}-0.0309^{* *} \\
(-2.3042)\end{array}$ & $\begin{array}{l}-0.5154^{* *} \\
(-2.2314)\end{array}$ & $\begin{array}{l}-0.1813^{*} \\
(-2.3551)\end{array}$ & $\begin{array}{l}-0.0772^{* *} \\
(-2.3684)\end{array}$ & $\begin{array}{l}-0.0533^{* *} \\
(-2.5215)\end{array}$ & $\begin{array}{c}-0.1018 \\
(-2.6017)\end{array}$ & $\begin{array}{l}-0.3263^{*} \\
(-2.6551)\end{array}$ & $\begin{array}{l}-0.1249^{* *} \\
(-2.4345)\end{array}$ & $\begin{array}{l}-0.1847^{* *} \\
(-2.6222)\end{array}$ & $\begin{array}{l}-0.0456^{* *} \\
(-2.3516)\end{array}$ \\
\hline
\end{tabular}

Panel B: Model Diagnostics

\begin{tabular}{|c|c|c|c|c|c|c|c|c|c|c|c|}
\hline & AT & $\mathbf{B E}$ & FI & FR & GE & GR & IE & IT & NL & PT & SP \\
\hline Adjusted $R^{2}$ & 0.5066 & 0.5699 & 0.6628 & 0.6362 & 0.6311 & 0.5993 & 0.6759 & 0.6516 & 0.6714 & 0.6315 & 0.6991 \\
\hline$D W$ Test & 2.3432 & 2.3579 & 2.4382 & 2.2609 & 2.4112 & 2.3516 & 2.2541 & 2.2603 & 2.2412 & 2.4211 & 2.3722 \\
\hline$\chi_{N}^{2}$ & $\begin{array}{c}1.8019 \\
{[0.4062]}\end{array}$ & $\begin{array}{c}2.6446 \\
{[0.2663]}\end{array}$ & $\begin{array}{c}3.1147 \\
{[0.2107]}\end{array}$ & $\begin{array}{c}1.5031 \\
{[0.4717]}\end{array}$ & $\begin{array}{c}0.3633 \\
{[0.8339]}\end{array}$ & $\begin{array}{c}3.2498 \\
{[0.1969]}\end{array}$ & $\begin{array}{c}1.6654 \\
{[0.4349]}\end{array}$ & $\begin{array}{c}1.6246 \\
{[0.4438]}\end{array}$ & $\begin{array}{c}1.2961 \\
{[0.5231]}\end{array}$ & $\begin{array}{c}0.4881 \\
{[0.7843]}\end{array}$ & $\begin{array}{c}1.1778 \\
{[0.5599]}\end{array}$ \\
\hline$\chi^{2} s C$ & $\begin{array}{c}0.7221 \\
{[0.6972]}\end{array}$ & $\begin{array}{c}0.6737 \\
{[0.5991]}\end{array}$ & $\begin{array}{c}0.6935 \\
{[0.7070]}\end{array}$ & $\begin{array}{c}2.3360 \\
{[0.3110]}\end{array}$ & $\begin{array}{c}0.4703 \\
{[0.8231]}\end{array}$ & $\begin{array}{c}0.5918 \\
{[0.7439]}\end{array}$ & $\begin{array}{c}0.7039 \\
{[0.7033]}\end{array}$ & $\begin{array}{c}3.2015 \\
{[0.2017]}\end{array}$ & $\begin{array}{c}1.9344 \\
{[0.3802]}\end{array}$ & $\begin{array}{c}0.3406 \\
{[0.8434]}\end{array}$ & $\begin{array}{c}3.4576 \\
{[0.1775]}\end{array}$ \\
\hline$\chi^{2} H$ & $\begin{array}{c}9.7357 \\
{[0.2841]}\end{array}$ & $\begin{array}{c}6.7833 \\
{[0.7457]}\end{array}$ & $\begin{array}{c}6.6370 \\
{[0.5763]}\end{array}$ & $\begin{array}{c}5.3963 \\
{[0.6117]}\end{array}$ & $\begin{array}{c}6.4655 \\
{[0.4973]}\end{array}$ & $\begin{array}{c}2.6931 \\
{[0.9521]}\end{array}$ & $\begin{array}{c}8.7579 \\
{[0.2707]}\end{array}$ & $\begin{array}{c}7.3818 \\
{[0.4961]}\end{array}$ & $\begin{array}{l}10.3646 \\
{[0.2404]}\end{array}$ & $\begin{array}{c}4.8097 \\
{[0.7777]}\end{array}$ & $\begin{array}{c}10.5802 \\
{[0.2266]}\end{array}$ \\
\hline
\end{tabular}

Notes: $\quad$ AT, BE, FI, FR, GE, GR, IE, IT, NL, PT and SP stand for Austria, Belgium, Finland, France, Germany, Greece, Ireland, Italy, the Netherlands, Portugal and Spain respectively.

In the ordinary brackets below the parameter estimates, the corresponding $t$-statistics are shown, based on the heteroskedasticity and autocorrelation consistent standard errors proposed by Newey and West (1987).

$\chi^{2} \mathrm{~N}, \chi^{2} \mathrm{SC}$ and $\chi^{2} \mathrm{H}$ are the Jarque-Bera test for normality, the Breusch-Godfrey LM test for second-order serial correlation and the Breusch-Pagan-Godfrey test for heteroskedasticity. In the square brackets, the associated probability values are given.

${ }^{*}$ and ${ }^{* *}$ denote significance at the $1 \%$ and $5 \%$ level, respectively. 
Table 2: Threshold model estimation results

\begin{tabular}{|c|c|c|c|c|c|c|c|c|c|c|c|}
\hline \multicolumn{12}{|c|}{ Panel A: Estimation results } \\
\hline & AT & $\mathbf{B E}$ & FI & FR & GE & GR & IE & IT & NL & PT & SP \\
\hline$g_{t-1}$ & $\begin{array}{l}0.3648^{*} \\
(3.1862)\end{array}$ & $\begin{array}{c}0.0907^{*} \\
(2.8003)\end{array}$ & $\begin{array}{l}0.0932^{*} \\
(2.7241)\end{array}$ & $\begin{array}{c}0.3842^{*} \\
(3.7111)\end{array}$ & $\begin{array}{l}0.0942^{*} \\
(2.7181)\end{array}$ & $\begin{array}{c}0.4042^{*} \\
(3.2924)\end{array}$ & $\begin{array}{c}0.3397^{*} \\
(2.7037)\end{array}$ & $\begin{array}{c}0.3736^{*} \\
(3.2115)\end{array}$ & $\begin{array}{c}0.3436^{*} \\
(2.8661)\end{array}$ & $\begin{array}{l}0.2879^{\text {** }} \\
(2.4514)\end{array}$ & $\begin{array}{l}0.6492^{*} \\
(3.1016)\end{array}$ \\
\hline$I N F_{t}$ & $\begin{array}{l}-0.0610^{*} \\
(-2.9272)\end{array}$ & $\begin{array}{l}-0.0161^{* *} \\
(-2.2725)\end{array}$ & $\begin{array}{l}-0.0278^{* *} \\
(-2.6015)\end{array}$ & $\begin{array}{l}-0.0647^{* *} \\
(-2.3243)\end{array}$ & $\begin{array}{l}-0.1662^{*} \\
(-2.6891)\end{array}$ & $\begin{array}{l}-0.1635^{* *} \\
(-2.5342)\end{array}$ & $\begin{array}{l}-0.1133^{* *} \\
(-2.4715)\end{array}$ & $\begin{array}{l}-0.0043^{* *} \\
(-2.3451)\end{array}$ & $\begin{array}{l}-0.0380^{*} \\
(-2.6655)\end{array}$ & $\begin{array}{l}-0.0774^{* *} \\
(-2.3771)\end{array}$ & $\begin{array}{l}-0.0434^{* *} \\
(-2.3561)\end{array}$ \\
\hline$\Delta H K_{t}$ & $\begin{array}{l}1.7884^{* *} \\
(2.6473)\end{array}$ & $\begin{array}{l}0.1510^{* * *} \\
(2.3815)\end{array}$ & $\begin{array}{c}1.0678^{*} \\
(2.9711)\end{array}$ & $\begin{array}{l}1.3752^{* *} \\
(2.3371)\end{array}$ & $\begin{array}{l}1.4776^{*} \\
(2.8560)\end{array}$ & $\begin{array}{l}4.5210^{*} \\
(2.7027)\end{array}$ & $\begin{array}{c}6.2846^{*} \\
(3.1442)\end{array}$ & $\begin{array}{l}0.5810^{* *} \\
(2.6261)\end{array}$ & $\begin{array}{l}0.2169^{* *} \\
(2.3241)\end{array}$ & $\begin{array}{l}1.3216^{* *} \\
(2.4241)\end{array}$ & $\begin{array}{l}0.7288^{* *} \\
(2.3230)\end{array}$ \\
\hline$\triangle$ OPEN $_{t}$ & $\begin{array}{l}0.2392^{*} \\
(3.1217)\end{array}$ & $\begin{array}{c}0.0981^{*} \\
(3.1434)\end{array}$ & $\begin{array}{c}0.2838^{*} \\
(4.1922)\end{array}$ & $\begin{array}{l}0.1658^{* *} \\
(2.3548)\end{array}$ & $\begin{array}{l}0.2855^{*} \\
(3.6808)\end{array}$ & $\begin{array}{l}0.0560^{* *} \\
(2.4128)\end{array}$ & $\begin{array}{l}0.1218^{* *} \\
(2.6525)\end{array}$ & $\begin{array}{c}0.3615^{*} \\
(3.2331)\end{array}$ & $\begin{array}{c}0.1057^{*} \\
(3.0910)\end{array}$ & $\begin{array}{l}0.1006^{* *} \\
(2.3346)\end{array}$ & $\begin{array}{l}0.2405^{*} \\
(2.6919)\end{array}$ \\
\hline POPGROt $_{t}$ & $\begin{array}{l}0.8572^{* *} \\
(2.3587)\end{array}$ & $\begin{array}{l}2.5998^{*} \\
(3.1942)\end{array}$ & $\begin{array}{l}2.6089^{* * *} \\
(2.5020)\end{array}$ & $\begin{array}{l}1.9275^{* *} \\
(2.6321)\end{array}$ & $\begin{array}{l}0.3057^{* *} \\
(2.4766)\end{array}$ & $\begin{array}{l}1.7582^{* *} \\
(2.5006)\end{array}$ & $\begin{array}{l}0.2476^{* *} \\
(2.5771)\end{array}$ & $\begin{array}{l}1.2511^{* *} \\
(2.5927)\end{array}$ & $\begin{array}{c}1.4051^{*} \\
(2.7316)\end{array}$ & $\begin{array}{c}1.9496^{*} \\
(2.8416)\end{array}$ & $\begin{array}{l}0.8891^{*} \\
(2.5802)\end{array}$ \\
\hline$G C F_{t}$ & $\begin{array}{c}0.6005^{*} \\
(2.6678)\end{array}$ & $\begin{array}{c}0.1198^{*} \\
(4.6411)\end{array}$ & $\begin{array}{c}0.1600^{*} \\
(4.2623)\end{array}$ & $\begin{array}{l}0.0512^{* *} \\
(2.3243)\end{array}$ & $\begin{array}{c}0.0549^{*} \\
(2.8793)\end{array}$ & $\begin{array}{l}0.4746^{* *} \\
(2.3616)\end{array}$ & $\begin{array}{l}0.0911^{* *} \\
(2.3711)\end{array}$ & $\begin{array}{l}0.0843^{* *} \\
(2.6116)\end{array}$ & $\begin{array}{c}0.6847^{*} \\
(3.1671)^{*}\end{array}$ & $\begin{array}{c}0.1278^{*} \\
(4.2111)\end{array}$ & $\begin{array}{l}0.0790^{* *} \\
(2.6234)\end{array}$ \\
\hline$\Delta d_{t} I\left(d_{t}>d^{*}\right)$ & $\begin{array}{l}-0.1778^{*} \\
(-2.7815)\end{array}$ & $\begin{array}{c}-0.7263^{*} \\
(-3.7814)\end{array}$ & $\begin{array}{c}-0.7716^{*} \\
(-5.0371)\end{array}$ & $\begin{array}{l}-1.0077^{*} \\
(-3.6276)\end{array}$ & $\begin{array}{c}-0.6148^{*} \\
(-3.6115)\end{array}$ & $\begin{array}{l}-0.1502^{*} \\
(-2.9015)\end{array}$ & $\begin{array}{l}-0.3130^{*} \\
(-3.1051)\end{array}$ & $\begin{array}{l}-0.1786^{*} \\
(-2.7912)\end{array}$ & $\begin{array}{l}-0.2698^{*} \\
(-2.8334)\end{array}$ & $\begin{array}{c}-0.3773^{*} \\
(-4.2510)\end{array}$ & $\begin{array}{c}-0.1879^{*} \\
(-2.7711)\end{array}$ \\
\hline$\Delta d_{t} I\left(d_{t}<d^{*}\right)$ & $\begin{array}{c}0.0579^{*} \\
(2.7145)\end{array}$ & $\begin{array}{l}0.1256^{* *} \\
(2.4920)\end{array}$ & $\begin{array}{c}0.4932^{*} \\
(3.9631)\end{array}$ & $\begin{array}{l}0.1714^{* *} \\
(2.4142)\end{array}$ & $\begin{array}{l}0.1959^{*} \\
(2.8436)\end{array}$ & $\begin{array}{l}0.2559^{*} \\
(2.8771)\end{array}$ & $\begin{array}{c}0.2130^{*} \\
(3.8233)\end{array}$ & $\begin{array}{l}0.0648^{*} \\
(2.6818)\end{array}$ & $\begin{array}{l}0.1647^{* *} \\
(2.5671)\end{array}$ & $\begin{array}{l}0.0485^{* *} \\
(2.3516)\end{array}$ & $\begin{array}{l}0.0211^{* *} \\
(2.2414)\end{array}$ \\
\hline$d^{*}$ & $\begin{array}{c}28 \% \\
{[1977]}\end{array}$ & $\begin{array}{c}61 \% \\
{[1970]}\end{array}$ & $\begin{array}{c}40 \% \\
{[1992]}\end{array}$ & $\begin{array}{c}21 \% \\
{[1978]}\end{array}$ & $\begin{array}{c}55 \% \\
{[1995]}\end{array}$ & $\begin{array}{c}59 \% \\
{[1989]}\end{array}$ & $\begin{array}{c}50 \% \\
{[1976]}\end{array}$ & $\begin{array}{c}41 \% \\
{[1971]}\end{array}$ & $\begin{array}{c}38 \% \\
{[1974]}\end{array}$ & $\begin{array}{c}37 \% \\
{[1981]}\end{array}$ & $\begin{array}{c}52 \% \\
{[1993]}\end{array}$ \\
\hline
\end{tabular}

Panel B: Model Diagnostics

\begin{tabular}{|c|c|c|c|c|c|c|c|c|c|c|c|}
\hline & AT & $\mathbf{B E}$ & FI & FR & GE & GR & IE & IT & NL & PT & SP \\
\hline Adjusted $R^{2}$ & 0.5066 & 0.5644 & 0.6778 & 0.6706 & 0.6541 & 0.6021 & 0.6954 & 0.6567 & 0.6759 & 0.6379 & 0.7168 \\
\hline DW Test & 2.3432 & 2.3426 & 2.4117 & 2.2476 & 2.4415 & 2.3853 & 2.2678 & 2.2655 & 2.2541 & 2.4083 & 2.3421 \\
\hline$\chi^{2} N$ & $\begin{array}{l}1.68281 \\
{[0.4311]}\end{array}$ & $\begin{array}{c}0.7051 \\
{[0.6720]}\end{array}$ & $\begin{array}{c}1.4800 \\
{[0.4771]}\end{array}$ & $\begin{array}{c}2.8600 \\
{[0.2393]}\end{array}$ & $\begin{array}{c}0.0537 \\
{[0.9735]}\end{array}$ & $\begin{array}{c}3.1281 \\
{[0.1969]}\end{array}$ & $\begin{array}{c}1.3685 \\
{[0.5045]}\end{array}$ & $\begin{array}{c}0.9928 \\
{[0.6215]}\end{array}$ & $\begin{array}{c}0.7728 \\
{[0.6795]}\end{array}$ & $\begin{array}{c}0.4881 \\
{[0.7843]}\end{array}$ & $\begin{array}{c}1.1778 \\
{[0.5599]}\end{array}$ \\
\hline$\chi^{2} s c$ & $\begin{array}{c}1.8910 \\
{[0.3885]}\end{array}$ & $\begin{array}{c}2.5622 \\
{[0.2777]}\end{array}$ & $\begin{array}{c}0.6935 \\
{[0.7070]}\end{array}$ & $\begin{array}{c}1.0346 \\
{[0.5961]}\end{array}$ & $\begin{array}{c}0.4403 \\
{[0.8024]}\end{array}$ & $\begin{array}{c}0.8994 \\
{[0.6378]}\end{array}$ & $\begin{array}{c}0.5570 \\
{[0.7569]}\end{array}$ & $\begin{array}{c}3.1207 \\
{[0.2101]}\end{array}$ & $\begin{array}{c}2.8994 \\
{[0.2353]}\end{array}$ & $\begin{array}{c}0.2147 \\
{[0.8982]}\end{array}$ & $\begin{array}{c}4.1838 \\
{[0.1235]}\end{array}$ \\
\hline$\chi^{2} H$ & $\begin{array}{c}4.6661 \\
{[0.7926]}\end{array}$ & $\begin{array}{c}6.7833 \\
{[0.7457]}\end{array}$ & $\begin{array}{c}8.9735 \\
{[0.3445]}\end{array}$ & $\begin{array}{c}5.3963 \\
{[0.6117]}\end{array}$ & $\begin{array}{c}9.0188 \\
{[0.3407]}\end{array}$ & $\begin{array}{c}6.3616 \\
{[0.6068]}\end{array}$ & $\begin{array}{c}9.0652 \\
{[0.3368]}\end{array}$ & $\begin{array}{l}11.3425 \\
{[0.1830]}\end{array}$ & $\begin{array}{l}12.1291 \\
{[0.1455]}\end{array}$ & $\begin{array}{c}5.0279 \\
{[0.7546]}\end{array}$ & $\begin{array}{c}8.5501 \\
{[0.3817]}\end{array}$ \\
\hline
\end{tabular}

Notes: $\quad$ AT, BE, FI, FR, GE, GR, IE, IT, NL, PT and SP stand for Austria, Belgium, Finland, France, Germany, Greece, Ireland, Italy, the Netherlands, Portugal and Spain respectively.

$d^{*}$ indicates the estimated threshold in the debt/GDP ratio and, in the square brackets below them, we present the year when the threshold is reached.

In the ordinary brackets below the parameter estimates, the corresponding $t$-statistics are shown, based on the heteroskedasticity and autocorrelation consistent standard errors proposed by Newey and West (1987).

$\chi^{2} \mathrm{~N}, \chi^{2} \mathrm{SC}$ and $\chi^{2} \mathrm{H}$ are the Jarque-Bera test for normality, the Breusch-Godfrey LM test for second-order serial correlation and the Breusch-Pagan-Godfrey test for heteroskedasticity. In the square brackets, the associated probability values are given.

${ }^{*}$ and ${ }^{* *}$ denote significance at the $1 \%$ and $5 \%$ level, respectively. 
Table 3: Contribution of each explanatory variable to the growth rate

\begin{tabular}{|c|c|c|c|c|c|c|c|c|c|c|c|}
\hline & AT & BE & FI & FR & GE & GR & IE & IT & NL & PT & SP \\
\hline Asymmetric model & & & & & & & & & & & \\
\hline$g_{t-1}$ & 0.0016 & 0.1056 & 0.0450 & 0.5658 & 0.1125 & 0.0565 & 0.1944 & 0.2238 & 0.0319 & 0.2119 & 0.4080 \\
\hline$I N F_{t}$ & -0.0005 & -0.0108 & -0.0132 & -0.1778 & -0.3927 & -0.0522 & -0.1380 & -0.0492 & -0.0212 & -0.1262 & -0.0466 \\
\hline$\Delta H K_{t}$ & 0.7171 & 0.0183 & 0.0322 & 0.1257 & 0.0886 & 0.1013 & 0.2010 & 0.0257 & 0.0009 & 0.1152 & 0.0432 \\
\hline$\triangle O P E N_{t}$ & 0.0040 & 0.0502 & 0.0424 & 0.0806 & 0.2588 & 0.0034 & 0.0185 & 0.0615 & 0.0082 & 0.0147 & 0.0469 \\
\hline POPGRO $_{t}$ & 0.0082 & 0.2102 & 0.3765 & 0.2347 & 0.0644 & 0.0716 & 0.0303 & 0.1541 & 0.0501 & 0.1120 & 0.1638 \\
\hline$G C F_{t}$ & 0.2733 & 0.7456 & 0.6363 & 0.8484 & 1.2937 & 0.8304 & 1.0688 & 0.8669 & 0.9412 & 0.9263 & 0.4568 \\
\hline$\Delta d_{t} I\left(\Delta d_{t}>0\right)$ & -0.0045 & -0.1298 & -0.2032 & -0.7330 & -0.4532 & -0.0132 & -0.4406 & -0.3362 & -0.0181 & -0.2837 & -0.0830 \\
\hline$\Delta d_{t} I\left(\Delta d_{t}<0\right)$ & 0.0006 & 0.0108 & 0.0842 & 0.0555 & 0.0279 & 0.0018 & 0.0655 & 0.0532 & 0.0070 & 0.0297 & 0.0110 \\
\hline Explained & 2.1381 & 2.2719 & 2.5073 & 2.1618 & 2.0855 & 2.1618 & 3.2127 & 2.0469 & 1.9592 & 2.9446 & 2.5073 \\
\hline Threshold model & & & & & & & & & & & \\
\hline$g_{t-1}$ & 0.0015 & 0.0617 & 0.0448 & 0.4573 & 0.1510 & 0.0733 & 0.3202 & 0.2513 & 0.0406 & 0.2094 & 0.4058 \\
\hline$I N F_{t}$ & -0.0004 & -0.0191 & -0.0262 & -0.1375 & -0.5497 & -0.0530 & -0.1442 & -0.0063 & -0.0103 & -0.0846 & -0.0531 \\
\hline$\Delta H K_{t}$ & 0.7145 & 0.0083 & 0.0481 & 0.1674 & 0.2414 & 0.0839 & 0.4642 & 0.0432 & 0.0018 & 0.1039 & 0.0427 \\
\hline$\triangle O P E N_{t}$ & 0.0035 & 0.0509 & 0.0460 & 0.0602 & 0.2443 & 0.0051 & 0.0759 & 0.0730 & 0.0087 & 0.0211 & 0.0506 \\
\hline POPGRO $_{t}$ & 0.0079 & 0.2876 & 0.3620 & 0.6496 & 0.0563 & 0.0904 & 0.0638 & 0.1485 & 0.0567 & 0.1375 & 0.1603 \\
\hline$G C F_{t}$ & 0.2766 & 0.8200 & 0.7029 & 0.6327 & 0.9930 & 0.8951 & 0.5539 & 0.5923 & 0.9093 & 0.7885 & 0.4508 \\
\hline$\Delta d_{t}\left(d_{t}<d^{*}\right)$ & 0.0001 & 0.0091 & 0.0033 & 0.0242 & 0.0810 & 0.0088 & 0.0079 & 0.0027 & 0.0059 & 0.0019 & 0.0002 \\
\hline$\Delta d_{t} I\left(d_{t}>d^{*}\right)$ & -0.0036 & -0.2191 & -0.1810 & -0.8539 & -0.2173 & -0.1016 & -0.3418 & -0.1047 & -0.0127 & -0.1778 & -0.0573 \\
\hline Explained & 2.1886 & 2.2672 & 2.5081 & 2.1536 & 2.1127 & 2.1652 & 3.7336 & 2.0817 & 1.9385 & 2.9631 & 2.5370 \\
\hline
\end{tabular}

\begin{tabular}{|c|c|c|c|c|c|c|c|c|c|c|c|}
\hline Observed & 2.3619 & 2.2357 & 2.5387 & 2.1517 & 2.0488 & 2.1517 & 3.7567 & 1.9941 & 2.0417 & 2.9489 & 2.5387 \\
\hline
\end{tabular}

Notes: $\quad$ AT, BE, FI, FR, GE, GR, IE, IT, NL, PT and SP stand for Austria, Belgium, Finland, France, Germany, Greece, Ireland, Italy, the Netherlands, Portugal and Spain respectively.

The contributions are normalized to 1 . 
Table 4: Forecast accuracy

\begin{tabular}{|c|c|c|c|c|c|c|c|c|c|c|c|}
\hline & $\mathbf{A T}$ & BE & FI & FR & $\mathbf{G E}$ & GR & IE & IT & NL & PT & SP \\
\hline $\begin{array}{c}\text { Asymmetric model } \\
\qquad \begin{array}{c}\text { RMSE } \\
\text { MAE } \\
\text { MAPE } \\
\text { SMAPE } \\
\text { Theil's } U_{1} \\
\text { Theil's } U_{2}\end{array}\end{array}$ & $\begin{array}{c} \\
\mathbf{1 . 6 8 2 2} \\
\mathbf{1 . 2 7 2 8} \\
\mathbf{2 4 5 . 7 6 4 3} \\
68.9455 \\
\mathbf{0 . 3 0 1 4} \\
0.4092\end{array}$ & $\begin{array}{c}1.4986 \\
1.1977 \\
107.4667 \\
64.2291 \\
0.2680 \\
\mathbf{0 . 3 2 6 1}\end{array}$ & $\begin{array}{c}1.7829 \\
\mathbf{1 . 4 3 0 8} \\
228.8803 \\
\mathbf{6 0 . 9 8 2 2} \\
0.2322 \\
\mathbf{0 . 5 7 6 5}\end{array}$ & $\begin{array}{c}1.3404 \\
1.1123 \\
118.2404 \\
\mathbf{6 5 . 9 2 6 0} \\
0.2476 \\
0.8058\end{array}$ & $\begin{array}{c}1.3729 \\
\mathbf{1 . 0 6 8 4} \\
\mathbf{1 2 8 . 8 6 5 7} \\
64.9815 \\
0.2526 \\
\mathbf{0 . 6 8 5 6}\end{array}$ & $\begin{array}{c}3.4865 \\
2.7963 \\
\mathbf{2 2 4 . 1 0 4 6} \\
93.0946 \\
0.4214 \\
\mathbf{0 . 8 7 7 8}\end{array}$ & $\begin{array}{c}2.1692 \\
\mathbf{1 . 6 3 8 5} \\
\mathbf{8 0 . 2 7 6 1} \\
66.1567 \\
0.1950 \\
0.2470\end{array}$ & $\begin{array}{c}1.9725 \\
1.6361 \\
\mathbf{1 8 3 . 8 3 0 2} \\
82.3025 \\
\mathbf{0 . 3 3 9 7} \\
\mathbf{0 . 2 4 5 7}\end{array}$ & $\begin{array}{c}1.3721 \\
1.1049 \\
63.3426 \\
\mathbf{6 8 . 3 2 1 9} \\
\mathbf{0 . 2 5 8 4} \\
0.5860\end{array}$ & $\begin{array}{c}2.3637 \\
1.9034 \\
194.9332 \\
71.5568 \\
0.2714 \\
0.5292\end{array}$ & $\begin{array}{c}1.9586 \\
1.5217 \\
98.0630 \\
75.5680 \\
0.2922 \\
0.5312\end{array}$ \\
\hline $\begin{array}{c}\text { Threshold model } \\
\text { RMSE } \\
\text { MAE } \\
\text { MAPE } \\
\text { SMAPE } \\
\text { Theil's } U_{1} \\
\text { Theil's } U_{2}\end{array}$ & $\begin{array}{c}1.7144 \\
1.3341 \\
274.6975 \\
\mathbf{6 8 . 6 0 4 4} \\
0.3069 \\
\mathbf{0 . 3 8 8 3}\end{array}$ & $\begin{array}{c}\mathbf{1 . 3 4 1 5} \\
\mathbf{1 . 0 9 1 7} \\
\mathbf{9 8 . 7 8 1 0} \\
\mathbf{5 7 . 7 6 1 8} \\
\mathbf{0 . 2 3 5 1} \\
0.4181\end{array}$ & $\begin{array}{c}\mathbf{1 . 7 6 3 7} \\
1.4445 \\
\mathbf{2 2 6 . 2 9 8 2} \\
62.4967 \\
\mathbf{0 . 2 2 9 7} \\
0.6191\end{array}$ & $\begin{array}{c}1.2649 \\
1.0925 \\
108.1447 \\
67.3532 \\
0.2312 \\
0.7518\end{array}$ & $\begin{array}{c}\mathbf{1 . 3 2 6 7} \\
1.0988 \\
131.18176 \\
\mathbf{6 0 . 7 4 3 9} \\
\mathbf{0 . 2 3 7 7} \\
0.8515\end{array}$ & $\begin{array}{c}\mathbf{3 . 4 5 1 5} \\
\mathbf{2 . 6 8 9 8} \\
239.1299 \\
\mathbf{8 3 . 9 5 4 7} \\
\mathbf{0 . 4 0 5 2} \\
0.9860\end{array}$ & $\begin{array}{c}\mathbf{1 . 9 6 4 9} \\
1.6428 \\
152.8034 \\
\mathbf{6 3 . 4 0 6 2} \\
\mathbf{0 . 1 7 4 2} \\
\mathbf{0 . 1 3 7 5}\end{array}$ & $\begin{array}{c}1.9945 \\
1.6918 \\
224.6151 \\
\mathbf{8 0 . 6 1 5 4} \\
0.3561 \\
0.3945\end{array}$ & $\begin{array}{c}1.5905 \\
1.2960 \\
88.5590 \\
75.0829 \\
0.3021 \\
0.6890\end{array}$ & $\begin{array}{c}2.3166 \\
1.8343 \\
175.5161 \\
70.7161 \\
0.2533 \\
0.4181\end{array}$ & $\begin{array}{c}1.8654 \\
1.4344 \\
91.5161 \\
64.617 \\
0.2671 \\
0.4366\end{array}$ \\
\hline
\end{tabular}

Notes: $\quad$ AT, BE, FI, FR, GE, GR, IE, IT, NL, PT and SP stand for Austria, Belgium, Finland, France, Germany, Greece, Ireland, Italy, the Netherlands, Portugal and Spain respectively.

RMSE is the Root Mean Square Error, MAE is the Mean Absolute Error, MAPE is the Mean Absolute Percentage Error, Theil's $\mathrm{U}_{1}$ is the Theil Inequality coefficient of forecast accuracy, and Theil's $\mathrm{U}_{2}$ is the Theil Inequality coefficient of forecast quality. Bold values indicate the forecast that performed the best under each of the evaluation statistics. 
Table 5: Asymmetric model: Pre- EMU and EMU estimation analysis

\begin{tabular}{|c|c|c|c|c|c|c|c|c|c|c|c|c|}
\hline & & AT & BE & FI & FR & GE & GR & IE & IT & NL & PT & SP \\
\hline \multirow[t]{2}{*}{ Pre-EMU } & $\hat{\beta}_{1}^{\operatorname{Pr} e-E M U}$ & $\begin{array}{l}-0.0912^{* * *} \\
(-2.8521)\end{array}$ & $\begin{array}{l}-0.1837^{* * *} \\
(-2.6412)\end{array}$ & $\begin{array}{c}-0.7750^{*} \\
(-2.7671)\end{array}$ & $\begin{array}{l}-0.6873^{*} \\
(-2.9212)\end{array}$ & $\begin{array}{l}-0.5771^{*} \\
(-2.6719)\end{array}$ & $\begin{array}{l}-0.3347^{*} \\
(-2.7721)\end{array}$ & $\begin{array}{l}-0.5045^{*} \\
(-2.7411)\end{array}$ & $\begin{array}{l}-0.5892^{*} \\
(-2.7612)\end{array}$ & $\begin{array}{l}-0.4527^{*} \\
(-2.7356)\end{array}$ & $\begin{array}{c}-0.3869 \\
(-2.7223)\end{array}$ & $\begin{array}{l}-0.1683^{*} \\
(-2.7544)\end{array}$ \\
\hline & $\hat{\beta}_{2}^{\operatorname{Pr} e-E M U}$ & $\begin{array}{l}-0.0393^{*} \\
(-2.9151)\end{array}$ & $\begin{array}{l}-0.0885^{* *} \\
(-2.5716)\end{array}$ & $\begin{array}{l}-0.6005^{* *} \\
(-2.6512)\end{array}$ & $\begin{array}{l}-0.1068^{*} \\
(-2.6616)\end{array}$ & $\begin{array}{l}-0.1810^{* *} \\
(-2.6155)\end{array}$ & $\begin{array}{l}-0.0994^{*} \\
(-2.6812)\end{array}$ & $\begin{array}{l}-0.2291^{*} \\
(-2.8312)\end{array}$ & $\begin{array}{l}-0.4766^{*} \\
(-2.6574)\end{array}$ & $\begin{array}{l}-0.2441^{*} \\
(-2.6671)\end{array}$ & $\begin{array}{l}-0.1351^{* *} \\
(-2.6515)\end{array}$ & $\begin{array}{l}-0.0526^{*} \\
(-2.8112)\end{array}$ \\
\hline \multirow[t]{2}{*}{ EMU } & $\hat{\beta}_{1}^{E M U}$ & $\begin{array}{l}-0.2485^{* *} \\
(-2.5512)\end{array}$ & $\begin{array}{l}-0.2888^{* *} \\
(-2.5613)\end{array}$ & $\begin{array}{l}-0.8632^{* *} \\
(-2.7817)\end{array}$ & $\begin{array}{l}-0.3863^{*} \\
(-2.8615)\end{array}$ & $\begin{array}{l}-0.1331^{*} \\
(-2.5667)\end{array}$ & $\begin{array}{l}-0.3229^{*} \\
(-2.7662)\end{array}$ & $\begin{array}{l}-0.7365^{*} \\
(-2.7262)\end{array}$ & $\begin{array}{l}-0.3800^{*} \\
(-2.7132)\end{array}$ & $\begin{array}{l}-0.1236^{*} \\
(-2.7761)\end{array}$ & $\begin{array}{l}-0.4209^{*} \\
(-2.7659)\end{array}$ & $\begin{array}{l}-0.1334^{*} \\
(-2.8231)\end{array}$ \\
\hline & $\hat{\beta}_{2}^{E M U}$ & $\begin{array}{l}-0.1695^{*} \\
(-2.7412)\end{array}$ & $\begin{array}{l}-0.2199^{*} \\
(-2.7671)\end{array}$ & $\begin{array}{l}-0.3018^{*} \\
(-2.7771)\end{array}$ & $\begin{array}{l}-0.0775^{*} \\
(-2.6551)\end{array}$ & $\begin{array}{l}-0.0603^{*} \\
(-2.8235)\end{array}$ & $\begin{array}{l}-0.0429^{*} \\
(2.6761)\end{array}$ & $\begin{array}{l}-0.0134^{*} \\
(-2.6566)\end{array}$ & $\begin{array}{l}-0.1530^{*} \\
(-2.8278)\end{array}$ & $\begin{array}{l}-0.0578^{*} \\
(-2.8145)\end{array}$ & $\begin{array}{l}-0.1701^{*} \\
(2.8113)\end{array}$ & $\begin{array}{l}-0.0370^{*} \\
(-2.7548)\end{array}$ \\
\hline \multirow[t]{2}{*}{$\begin{array}{l}\text { Differences in } \\
\text { coefficients }\end{array}$} & $\hat{\beta}_{1}^{\operatorname{Pr} e-E M U}=\hat{\beta}_{1}^{E M U}$ & $\begin{array}{c}0.0911 \\
{[0.7628]}\end{array}$ & $\begin{array}{c}0.8694 \\
{[0.3511]}\end{array}$ & $\begin{array}{c}0.0793 \\
{[0.7783]}\end{array}$ & $\begin{array}{c}1.5980 \\
{[0.2062]}\end{array}$ & $\begin{array}{l}7.9275^{*} \\
{[0.0049]}\end{array}$ & $\begin{array}{c}0.0009 \\
{[09757]}\end{array}$ & $\begin{array}{l}2.8860^{* * *} \\
{[0.0894]}\end{array}$ & $\begin{array}{c}0.2566 \\
{[0.6125]}\end{array}$ & $\begin{array}{l}3.4028^{* * *} \\
{[0.0651]}\end{array}$ & $\begin{array}{c}0.0295 \\
{[0.8636]}\end{array}$ & $\begin{array}{c}0.0124 \\
{[0.9113]}\end{array}$ \\
\hline & $\hat{\beta}_{2}^{\operatorname{Pr} e-E M U}=\hat{\beta}_{2}^{E M U}$ & $\begin{array}{c}0.3876 \\
{[0.5336]}\end{array}$ & $\begin{array}{c}0.2891 \\
{[0.5908]}\end{array}$ & $\begin{array}{l}3.6572^{* * *} \\
{[0.0558]}\end{array}$ & $\begin{array}{c}0.0616 \\
{[0.8040]}\end{array}$ & $\begin{array}{c}0.8127 \\
{[0.3673]}\end{array}$ & $\begin{array}{c}0.0997 \\
{[0.7522]}\end{array}$ & $\begin{array}{l}5.4691^{* *} \\
{[0.0194]}\end{array}$ & $\begin{array}{l}5.2223^{* *} \\
{[0.0225]}\end{array}$ & $\begin{array}{c}0.0709 \\
{[0.7900]}\end{array}$ & $\begin{array}{c}0.0006 \\
{[0.9811]}\end{array}$ & $\begin{array}{c}0.0191 \\
{[0.8902]}\end{array}$ \\
\hline
\end{tabular}

Notes:

$\hat{\beta}_{1}$ and $\hat{\beta}_{2}$ are, respectively, the estimated coefficients capturing in equation (4) the effects on economic growth of positive and negative debt variations.

In the ordinary brackets below the parameter estimates, the corresponding $t$-statistics are shown, based on the heteroskedasticity and autocorrelation consistent standard errors proposed by Newey and West (1987).

Wald tests are Chi-square test statistics for significant differences in estimated coefficients. In the square brackets, the associated probability values are given.

${ }^{* * *}$ and ${ }^{* * *}$ denote significance at the $1 \%, 5 \%$ and $10 \%$ level, respectively. 
Table 6: Threshold model: Pre- EMU and EMU estimation analysis

\begin{tabular}{|c|c|c|c|c|c|c|c|c|c|c|c|c|}
\hline & & $\mathbf{A T}$ & $\mathbf{B E}$ & FI & FR & GE & GR & IE & IT & NL & PT & SP \\
\hline \multirow[t]{2}{*}{ Pre-EMU } & $\hat{\gamma}_{1}^{\operatorname{Pr} e-E M U}$ & $\begin{array}{l}0.0823^{*} \\
(2.8434)\end{array}$ & $\begin{array}{l}0.1035^{*} \\
(2.6876)\end{array}$ & $\begin{array}{l}0.4572^{*} \\
(2.7656)\end{array}$ & $\begin{array}{l}0.1301^{*} \\
(2.7769)\end{array}$ & $\begin{array}{l}0.2610^{*} \\
(2.9122)\end{array}$ & $\begin{array}{l}0.2046^{*} \\
(2.8142)\end{array}$ & $\begin{array}{l}0.1827^{*} \\
(2.8551)\end{array}$ & $\begin{array}{l}0.0262^{*} \\
(2.7671)\end{array}$ & $\begin{array}{l}0.1880^{*} \\
(2.9162)\end{array}$ & $\begin{array}{l}0.0480 \\
(2.8112)\end{array}$ & $\begin{array}{l}0.0228^{*} \\
(2.8661)\end{array}$ \\
\hline & $\hat{\gamma}_{2}^{\operatorname{Pr} e-E M U}$ & $\begin{array}{l}-0.1823^{*} \\
(-2.7761) \\
\end{array}$ & $\begin{array}{l}-0.6140^{*} \\
(-2.7767) \\
\end{array}$ & $\begin{array}{l}-0.8708^{*} \\
(-2.8273) \\
\end{array}$ & $\begin{array}{l}-1.0449^{*} \\
(-2.8762) \\
\end{array}$ & $\begin{array}{l}-0.9881^{*} \\
(-2.8655)\end{array}$ & $\begin{array}{l}-0.2403^{*} \\
(-2.7884) \\
\end{array}$ & $\begin{array}{l}-0.4914^{*} \\
(-2.7991) \\
\end{array}$ & $\begin{array}{l}-0.3218^{*} \\
(-2.8431) \\
\end{array}$ & $\begin{array}{l}-0.2706^{*} \\
(-2.8342) \\
\end{array}$ & $\begin{array}{c}-0.3519 \\
(-2.7861) \\
\end{array}$ & $\begin{array}{l}-0.2079^{*} \\
(-2.7781) \\
\end{array}$ \\
\hline \multirow[t]{2}{*}{ EMU } & $\hat{\gamma}_{1}^{E M U}$ & & & & & & & $\begin{array}{l}0.2070^{*} \\
(2.7761)\end{array}$ & & & & $\begin{array}{l}0.0335^{*} \\
(2.7882)\end{array}$ \\
\hline & $\hat{\gamma}_{2}^{E M U}$ & $\begin{array}{l}-0.1380^{*} \\
(-2.7856)\end{array}$ & $\begin{array}{l}-0.8604^{*} \\
(-2.8243)\end{array}$ & $\begin{array}{l}-0.8165^{* *} \\
(-2.8456)\end{array}$ & $\begin{array}{l}-1.2790^{*} \\
(-2.9541)\end{array}$ & $\begin{array}{l}-0.6321^{*} \\
(-2.8555)\end{array}$ & $\begin{array}{l}-0.1059^{*} \\
(-2.9341)\end{array}$ & $\begin{array}{l}-0.3729^{*} \\
(-2.8661)\end{array}$ & $\begin{array}{l}-0.3074^{*} \\
(-2.8442)\end{array}$ & $\begin{array}{l}-0.1706^{*} \\
(-2.9541)\end{array}$ & $\begin{array}{c}-0.2939 \\
(-2.7984) \\
\end{array}$ & $\begin{array}{l}-0.1268^{*} \\
(-2.8771)\end{array}$ \\
\hline \multirow[t]{2}{*}{$\begin{array}{l}\text { Differences in } \\
\text { coefficients }\end{array}$} & $\hat{\gamma}_{1}^{\operatorname{Pr} e-E M U}=\hat{\gamma}_{1}^{E M U}$ & & & & & & & $\begin{array}{c}0.4280 \\
{[0.5130]}\end{array}$ & & & & $\begin{array}{c}0.0223 \\
{[0.9620]}\end{array}$ \\
\hline & $\hat{\gamma}_{2}^{\operatorname{Pr} e-E M U}=\hat{\gamma}_{2}^{E M U}$ & $\begin{array}{c}0.1457 \\
{[07027]}\end{array}$ & $\begin{array}{c}0.8319 \\
{[0.3617]}\end{array}$ & $\begin{array}{c}0.0686 \\
{[0.7933]}\end{array}$ & $\begin{array}{c}0.2717 \\
{[0.6022]}\end{array}$ & $\begin{array}{l}3.0918^{* * * *} \\
{[0.0787]}\end{array}$ & $\begin{array}{c}0.5818 \\
{[0.4456]}\end{array}$ & $\begin{array}{c}0.1621 \\
{[0.6873]}\end{array}$ & $\begin{array}{c}0.0167 \\
{[0.8972]}\end{array}$ & $\begin{array}{c}0.3323 \\
{[0.5643]}\end{array}$ & $\begin{array}{c}0.1088 \\
{[0.7416]}\end{array}$ & $\begin{array}{c}0.3742 \\
{[0.5407]}\end{array}$ \\
\hline
\end{tabular}

Notes:

$\hat{\gamma}_{1}$ and $\hat{\gamma}_{2}$ are, respectively, the estimated coefficients capturing in equation (5) the effects on economic growth of debt variations below or above the detected threshold value.

During the EMU subsample, only for Ireland and Spain there are observations where $d_{t} \leq d^{*}$, so we can only test the null hypothesis $\hat{\gamma}_{1}^{\text {Pre-EMU }}=\hat{\gamma}_{1}^{E M U}$ for these two countries.

In the ordinary brackets below the parameter estimates, the corresponding $t$-statistics are shown, based on the heteroskedasticity and autocorrelation consistent standard errors proposed by Newey and West (1987).

Wald tests are Chi-square test statistics for significant differences in estimated coefficients. In the square brackets, the associated probability values are given.

${ }^{*},{ }^{* *}$ and ${ }^{* * *}$ denote significance at the $1 \%, 5 \%$ and $10 \%$ level, respectively. 